\title{
A BEFEKTETÉS-ÖSZTÖNZÉS REGIONÁLIS TAPASZTALATAI
}

\author{
(Regional Investment Promotion in Hungary)
}

\author{
SZALAVETZ ANDREA
}

\section{Bevezetö}

A decentralizált területfejlesztési intézményrendszer létrehozása, az állam és a települések között elhelyezkedö közigazgatási „ür” kitöltése a fejlett ipari országok intézményrendszerének hazai meghonositási folyamatában egyike volt a legkésöbb sorra kerülő feladatoknak. Eddig az első, legegyszerübben megtehető lépésekre, a területfejlesztésröl és területrendezésröl szóló törvény elfogadására és az intézményrendszer létrehozására került csak sor. Hátravan néhány alapvető, filozófiai jellegủ kérdés tisztázása. Melyek legyenek a decentralizált területfejlesztés alapegységei? Hány területfejlesztési szintet ismerjen el a központi hatalom, és milyen hatás- és felelősségi kört delegáljon az egyes szintekre? Milyen fokú legyen az állam és a régiók közötti hatalommegosztás? (A decentralizáció három lehetséges modelljéről lásd Horváth Gyula írását [1999].)

Jelen tanulmány nem a fenti elvi kérdésekre igyekszik választ adni, javaslatokat megfogalmazni. Célkitüzésünk ennél szerényebb, a decentralizáció jelenlegi rendszerét vizsgáljuk meg, az intézményrendszer hatékonyságát, lehetőségeit és korlátait kíséreljük meg feltérképezni.

\section{Módszertan}

A kutatás empirikus vizsgálatokra épült. Interjút készítettünk a területfejlesztésért felelős intézmények képviselőivel, elsősorban a Megyei Területfejlesztési Tanácsok (MTT) (12 megye), továbbá két regionális fejlesztési tanács és egyéb szervezetek (kamarák, regionális bank, terulletfejlesztési tanácsadással foglalkozó kft.) képviselöivel.

Az interjúk alapját egy 20 nyitott kérdésböl álló esettanulmány-vázlat képezte. A nyitott kérdések lehetőséget biztosítottak arra, hogy a megkérdezettek egyes témákra részletesebben térjenek ki.

A kutatás nem tekintette céljának, hogy összegyüjtse és elemezze azokat a konkrét, statisztikai módszerekkel feldolgozható adatokat, amelyek segítségével választ kaphatnánk olyan kérdésekre, hogy miként növekedtek a pályázatokon szétosztható keretösszegek, milyen arányban részesülttek támogatásban az egyes gazdaságfejlesztési és infrastrukturális célok, milyen összegü fejlesztéseket tettek a támogatá- 
sok lehetővé, melyek az egyes megyék utóbbi években elért konkrét gazdaságfejlesztési eredményei.

A fenti kérdések helyett, inkább azokra a nehezen számszerüsíthető tapasztalatokra voltunk kíváncsiak, hogy a néhány éve létrehozott intézmények regionális szinten ${ }^{1}$ milyen befektetés-ösztönzési eszközökkel rendelkeznek, megfigyelhetö-e súlyponteltolódás a célrendszerben, EU-konform-e a területfejlesztés, illetve melyek a legföbb hiányosságok az EU regionális fejlesztési cél- és eszközrendszerének hazai meghonosítása terén, miként lehetne fejleszteni a területfejlesztési, befektetésösztönzési szabályozórendszert stb.

Terjedelmi korlátok miatt csak utalásszerüen térhettünk ki a regionális politika intézményrendszerének hazai fejlődésére, a rendszerváltás utáni első időszakra (Horváth 1998a; 1998b). A tanulmány a területfejlesztés regionális intézményrendszerének jelenlegi múködését veszi nagyító alá a befektetés-ösztönzés tükrében.

\section{Befektetés-ösztönzés és területfejlesztés}

Az intézményrendszer müködésének tapasztalatain túlmenően arra voltunk kíváncsiak, hogy képesek-e a döntéshozók regionális politikai eszközökkel iparfejlesztési célokat megvalósítani? Melyek a gazdasági tevékenység regionális élénkítésének lehetőségei? Elösegítheti-e a regionális politika a gazdaság, ezen belül a feldolgozóipar szerkezetének modernizációját?

Az első, az interjúk során tisztázandó kérdés az volt, hogy milyen súlyt képvisel a befektetés-ösztönzés a területfejlesztési programokban? Van-e eltérés az egyes megyék fejlesztési prioritásainak sorrendjében?

$\mathrm{Az}$ interjúk tapasztalatai szerint a fejlesztési célok egyes megyékben kialakított prioritás-sorrendje szoros összefüggést mutat az adott megye fejlettségi szintjével. A gazdasági tevékenység sürüsége, intenzitása szempontjából relatíve elmaradottnak minösülő megyékben a fejlesztési célok közül az infrastruktúra-fejlesztés, a közmủellátottság javítása, a közlekedési hálózat fejlesztése fontosabb szerepet játszik, mint a befektetés-ösztönzés. Azokban a megyékben ugyanakkor, amelyekre viszonylag intenzívebb feldolgozóipari tevékenység jellemzö, a befektetésösztönzés hangsúlyosabb helyet foglal el a prioritások rangsorában.

A következtetések levonása elött két torzító tényezőt kell figyelembe vennünk. A képet egyrészt az torzítja, hogy a feldolgozóipari tevékenység intenzitása szempontjából jobb helyzetben lévő megyékben az infrastruktúra már eleve fejlettebb volt, mint az aprófalvas, a külföldi tőkebefektetők látóköréből kiesett, elmaradottabb megyékben.

A másik torzító tényezỏ a kétféle fejlesztéstípus eltérỏ költségigénye. Az infrasrukturális fejlesztések az infrastrukturális és nem infrastrukturális fejlesztésekre fordítható kereteket ${ }^{2}$ egyaránt sokszorosan kimerítik. A támogatási döntéseket megelöző viták egyik elvi „filozófiai” jellegü tisztázandó kérdése volt, hogy a területfejlesztési célelöirányzat keretét gazdaságfejlesztési célokra fordítsák-e, vagyis az egyes kereteket külön kezelve, többféle, egyenként viszonylag kisebb ráfordítás- 
igényü célokat valósítsanak meg, vagy egészítsék ki a Területi Kiegyenlítési Alapból folyósított infrastrukturális támogatásokat a területfejlesztési kerettel, és ez utóbbiból is infrastrukturális fejlesztéseket végezzenek.

$\mathrm{Az}$ egyes megyék tapasztalataiból azt a következtetést vonhatjuk le, hogy azokban a megyékben lehet sikeres befektetés-ösztönzési projekteket készíteni és támogatni, ahol már kialakult a gazdasági tevékenység viszonylag sủrủ hálózata. Mivel az elmaradott infrastrukturális hálózatok szük keresztmetszetet képezve a gazdaságfejlesztést is akadályozzák, a gazdaságilag és az alapvető infrastruktúra kiépítettsége tekintetében egyaránt elmaradott megyék első lépésként nem a befektetésösztönzés, hanem inkább az infrastruktúra, a közmü- és közlekedési hálózat fejlesztése mellett tették le a voksot. A befektetés-ösztönzés, gazdaságfejlesztés azokban a megyékben került a megyei fejlesztési stratégia fókuszába, ahol a feldolgozóipari tevékenység már viszonylag intenzívebb volt.

A befektetés-ösztönzés és az infrastruktúra fejlettsége közötti egyértelmü összefüggésre utal az a tény, hogy a külföldi befektetők telephely-döntéseit befolyásoló feltételek között kiemelt helyen szerepel az elérhetöség. A fejlesztési stratégiát kidolgozó szakértök meggyőződése szerint a befektetés-ösztönzési projektek akkor lesznek, lehetnek igazán sikeresek, akkor járnak majd a gazdasági tevékenység élénküléséhez vezető multiplikátor-hatással, ha az elérhetöséget és a kommunikációt biztosító alapvető infrastruktúra (és természetesen a kommunális szolgáltatások alapinfrastruktúrája) már kiépủlt.

„Ne is álmodjunk sikeres befektetés-ösztönzésröl addig - fejezte ki meggyőződését az egyik MTT képviselöje -, amíg ilyen fokú belviz- és szennyvízproblémák vannak, amíg ilyen tragikus a helyzet a hulladékgazdálkodás területén, amíg az országos úthálózatokkal való összeköttetés megoldatlan."

A telephely kiválasztás elött álló befektetök gyakran azzal a kéréssel fordulnak az MTT-khez, hogy adja meg az autópálya mellett fekvő települések névsorát, vagyis kiindulópontként, alapfeltételként kezelik az autópálya meglétét. Több MTT képviselöje is beszámolt arról, hogy az ủjonnan kiépített autópálya-szakaszok mellett érzékelhetöen, látványosan felgyorsult a fejlödés.

Más kérdés, hogy egy-egy, a térségbe betelepült multi maga is hozzájárulhat a müködését elösegítő infrastruktúra fejlesztéséhez. A multik megjelenése egyrészt meggyorsíthatja a folyamatot, hiszen gyakran infrastrukturális feltételekhez kötik a pozitív telephelydöntésüket, másrészt arra is akadt példa, hogy a betelepült vállalat maga is áldozott infrastrukturális fejlesztésekre (pl. Baranya megyében a Nokia hozzájárult a telephelyére szállító teherautók számára egy városon belüli mentesítő út megépítéséhez).

A multinacionális vállalatok komoly segítséget nyújthatnak, de meg is nehezíthetik a megyei területfejlesztési célok megvalósitását.

Bár mind Baranya megye, mind a Dél-Dunántúli Régió fejlesztési tervében hangsúlyos helyen szerepelt egy innovációs és technológia-fejlesztési központ létrehozása, és össze is állt a fejlesztésben részt vevő, gazdálkodó szervezetekböl, a Pécsi Ipari Park Rt.-böl valamint az egyéb szervekből álló konzorcium, a megyében gyártóbázissal rendelkezỏ Nokia 
ennek ellenére sem adott szándéknyilatkozatot arról, hogy kutatás-fejlesztést telepít az innovációs központba. Végül Debrecenben hozta létre $K+F$ központját - egyes vélemények szerint az elutasítás alapvető oka az volt, hogy a Dél-Dunántúli Régióban nincs jelentős müszaki felsőoktatási intézmény.

A Zala megyei MTT képviselője az elérhetőséget biztosító közlekedési hálózat fejlesztésének abszolút prioritását sajátos, ,negatív multiplikátor-hatással” magyarázta. Amennyiben a közlekedési összeköttetés nincs megfelelö szinten kiépítve, az egyéb infrastrukturális fejlesztések korábbi ráforditásai is elveszhetnek. Zala megye 257 településéböl kb. 100 annak ellenére van kihalásra itélve, hogy viszonylag fejlett a településen belüli infrastruktúra, kiépítettek a belterületi utak, jó állapotban van a lakásállomány, és a közművesítés is nagyrészt megtörtént. A fenti 100 település visszafordíthatatlannak tünő elöregedési folyamata arra vezethetö vissza, hogy az adott települést az országos közút- és vasúthálózattal összekötö közlekedési hálózat fejletlen, rossz állapotban van. Az ilyen településekről megindul az elvándorlás, és hiába fekszenek különbözö gazdaságfejlesztési célelöirányzatokból kiemelten támogatható térségekben, már projektek sincsenek, amelyeket támogatni lehetne. Az ezeket a településeket érintö, elsősorban megoldandó gazdaságfejlesztési kérdés tehát a közlekedési és a kommunikációs infrastruktúra fejlesztése, az országos hálózatokkal való összeköttetés kiépítése.

A kulcsszó az elérhetőség és az összeköttetés, nem pedig önmagában véve az infrastruktúra-fejlesztés. A kommunális fejlesztések és a belterületi közlekedési infrastruktúra fejlesztése nem jelent egyértelmủen fejlödést, felzárkózást a minden szempontból elmaradott települések számára. Ha ezek a célok élveznek abszolút prioritást a fejlesztési támogatásokból, könnyen eljuthatunk abba az állapotba, hogy egyes településeken a szennyvízrendszer kiépítettsége és az aszfaltozott utak aránya a száz százalékot közelíti, ugyanakkor a munkanélküliségi ráta továbbra is elviselhetetlenül magas és munkaalkalom továbbra sincsen. Kérdés, hogy munkahelyteremtö beruházások és a helyi gazdasági tevékenység intenzitásának növekedése nélkül miből fogják az egyes települések a költséges kommunális hálózatokat fenntartani? (Dancs 1999)

Tény, hogy sok MTT követi azt az elvet, hogy a decentralizált keretekb öl, a politikai béke fenntartása érdekében, lehetöleg minden pályázó önkormányzat legalább egy pályázaton nyertes legyen. Ennek következtében föként szétforgácsolt belterületi infrastrukturális fejlesztésekre: település-fejlesztésre és nem átfogó szemléletü területfejlesztésre kerül sor.

1991-94 között a Területfejlesztési Alapból nyújtott támogatások mintegy 80\%-a infrastrukturális támogatásokhoz kapcsolódott. 1994-től növekedni kezdett a gazdaság növekedését, az egyes térségek felzárkóztatását, a szerkezet-átalakítást és a munkahelyteremtést elősegítő támogatások aránya. 1997-ben ez az arány elérte az 59,3\%-ot ${ }^{4}$ (Szaló 1999). Ezzel együtt az Európai Unióban a támogatások jóval nagyobb arányát fordítják gazdaságfejlesztésre, befektetés-ösztönzésre, mint Magyarországon. A befektetés-ösztönzési lehetőségeket nem csupán a településfejlesztésben érdekelt „erős önkormányzati lobbi” határolja be, hanem a gazdaságfej- 
lesztésre fordítható támogatások célrendszerének szigorú körülhatárolása is. Befektetés-ösztönzési, gazdaságfejlesztési támogatások leginkább „munkahelyteremtés és -megörzés" címszóval (illetve ipari parkok és vállalkozási övezetek kialakítása címszóval) szerezhetők meg. A munkahelyteremtési támogatások megítélésekor azonban kettős fék lép életbe: a törvény szerint, a tervezett beruházás összértékének $30 \%$-át nem haladhatja meg a támogatás összege, amely az újonnan teremtett munkahelyenként maximum egymillió forintot érhet el. Egy 12 milliós fejlesztés például akkor sem részesülhet 4 millió forintot meghaladó támogatásban, ha a fejlesztéssel a pályázó 10 új munkahely létrehozását vállalná.

A munkahelyteremtési pályázatot elnyert cégeknek már a támogatás évében teljesíteniük kell a vállalt foglalkoztatási kötelezettségüket. Sok helyen, érdekes módon föként a magas munkanélküliségtöl sújtott területeken, a kapacitásukat és munkaerö-állományukat fejlesztő cégek nem képesek felvenni, és tartósan alkalmazni annyi új foglalkoztatottat, amennyit a pályázatukban vállaltak, mert a helyi munkaügyi központ nem tud megfelelő képzettségủ és hozzáállású szakmunkást kiközvetíteni. A vizsgált megyékben több ízben elöfordult, hogy az ellenỏrzés során kiderült, a támogatott cég nem bövítette foglalkoztatottainak számát a vállalt mértékben. A cégek általában bizonyítani tudták, hogy folyamatosan munkaerö-felvételt hirdetnek, bizonyítani tudták a kiközvetített, még csak nem is minimálbéren bejelentett munkások magas fluktuációját, sőt azt is, hogy a megnövekedett megrendelésállományukat, megfelelő számú foglalkoztatott híján, csak úgy voltak képesek teljesíteni, ha alvállalkozókat, beszállítókat foglalkoztattak. Mindazonáltal, a törvény értelmében, a végkövetkeztetés nem lehetett más csak az, hogy a pályázó kamatostul fizesse vissza a támogatás összegét.

A pályázók nagy része csak úgy tudta bővíteni foglalkoztatottai számát, ha a konkurens cégektől csábított el alkalmazottakat, vagyis nem a térségi munkanélküliség csökkent, hanem a bérszínvonal emelkedett.

Két következtetést vonhatunk le. Egyrészt a munkahelyteremtés és a beszállítói rendszer fejlesztése szorosan összefügg egymással, egymás kiegészítéseként is felfogható. Szükségtelen a két pályázati célkitủzés merev szétválasztása, nem célszerủ elutasítani azt a lehetőséget, hogy a pályázó a foglalkoztatást nem egyedül a saját cégénél, hanem alvállalkozóinál is bövítse, és így hajtsa végre összességében a vállalt mennyiségü munkahelyteremtést.

A másik következtetésünk a korábban tárgyalt „infrastruktúrafejlesztésre, vagy gazdaságélénkítésre helyezzünk-e először hangsúlyt?" kérdésre rímel. Az érvek és ellenérvek felsorolásából korábban azt a kővetkeztetést vontuk le, hogy bár a kérdést így feltenni irreleváns, komplex programokra van szükség, továbbá a különbözö infrastrukturális fejlesztések igencsak eltérö mértékben járulhatnak hozzá az elmaradott térségek felzárkóztatásához, modernizációjához, mégis van egy olyan infrastrukturális terület, ahol a gazdaságfejlesztés alapfeltétele a megfelelö kiépítettség. Befektetés-ösztönzési, munkahelyteremtési programok kizárólag abban az esetben lehetnek eredményesek, vezethetnek a gazdasági tevékenység élénkülésé- 
hez, ha a térség könnyen megközelíthető, ha jól kapcsolódik az országos közlekedési hálózatokhoz. A fenti „melyiket fejlesszük előbb?” kérdéshez hasonló a második következtetésünk. Elmaradott, magas munkanélküliségủ térségekben a munkahelyteremtési, gazdaságfejlesztési programok akkor vezetnek sikerre, ha előtte - jelentős forrásokat szánnak a munkanélküliek képzésére. Felmerül a „tyúk, vagy a tojás" probléma, hiszen a képzés, átképzés csak az igények ismeretében lehet hatékony. A munkahelyteremtést és az ehhez szükséges képzést olyan módon lehetne összehangolni, hogy a komplex programok jegyében egy-egy cég nem csupán munkahelyteremtésre kaphatna támogatást, hanem ez automatikusan kiegészuilne képzési támogatással. A rendelkezésre álló forrásokat növelné, ha a cégek által fizetett szakképzési hozzájárulást nem központi adónemként kezelnék, hanem az MTT-k decentralizált területfejlesztési keretét bővítenék vele.

A gazdaságfejlesztés munkahelyteremtéssel való szoros összefüggéséból adódik a másik probléma is: ha egy cég olyan technológiai korszerüsítést kívánna végrehajtani, amely versenyképességét javítaná, ám épp a technológia korszerüsödéséből kifolyólag a foglalkoztatottak száma csökkenne, a jelen pályázati rendszerben ehhez a beruházáshoz a cég nem kaphatna támogatást a területfejlesztési keretböl.

Ha úgy tesszük fel a kérdést, hogy a területfejlesztéshez, a gazdasági felzárkóztatáshoz az infrastruktúra-fejlesztés vagy befektetés-ösztönzés járul-e hatékonyabban hozzá; melyik célkitủzés élvezzen prioritást; milyen sorrendben kerüljön sor az egyes fejlesztésekre stb. - a valamelyik verziót elönyben részesítő érvek és ellenérvek, a fentiekhez hasonlóan még hosszan sorolhatók lennének. Ugyanakkor nem szabad megfeledkeznünk arról, hogy a „,befektetés-ösztönzés vagy infrastruktúrafejlesztés" kérdése irreleváns. A befektetés-ösztönzést nem lehet, nem szabad önmagában vizsgálni, hiszen az EU-konform területfejlesztési programkészítés egyik alapszabálya, hogy komplex regionális fejlesztési programok készüljenek. Ezekben a programokban az infrastruktúra-fejlesztés, munkahelyteremtés, vállalkozásösztönzés (versenyképes gazdaságszerkezet kialakítása) mellett olyan céloknak is szerepelniük kell, amelyek a felsorolt fö programelemekhez, az ezekre a célokra benyújtott projekt-pályázatokhoz kapcsolódnak, azokra hatást gyakorolnak (humán eröforrások fejlesztése, környezetvédelem stb.). Eszerint a komplex programkészítés jegyében befektetés-ösztönzésnek számítanak a megyei- és településmarketingre, humán erőforrások fejlesztésére, környezetvédelemre, sỏt az infrastruktúrafejlesztésre fordított összegek is.

\section{A megyei fejlesztési stratégiák kidolgozása}

A kilencvenes évek első felében (1996-ig) nem beszélhetünk tudatos, tervszerü területfejlesztési politikáról. A kilencvenes évek első fele, az 1990-es önkormányzati törvény értelmében, a megyei döntési szint negligálása jegyében telt ${ }^{4}$, a központi kormányzat elvileg csak a települések sokaságával kívánt kapcsolatot tartani. „A központi kormányzatnak nem volt 'területi ellenlábasa', az elaprózott települési 
önkormányzatok nem képeztek ellensúlyt a központi igazgatással szemben." (Hajdú 1999, 28)

Először az 1996-os területfejlesztési törvény tette kötelezövé, hogy megyei szinten fejlesztési stratégiát alakítsanak ki a területfejlesztéssel megbízott, erre a célra létrehozott szervezetek. ${ }^{5}$ Mindazonáltal, a megyék többsége már a kilencvenes évek első felében, társadalmi munkában kialakította fejlesztési koncepcióját. A megyék nagy része számos helyzetfelmérő, a későbbi koncepciót megalapozó tanulmányt és dokumentációt készített, így legtöbbjüknek az 1996-os törvényt követően már csak aktualizálni kellett a korábban kialakított fejlesztési koncepciót. A megyei szintet ugyanis sohasem negligálták egységesen. Az önkormányzati törvény értelmében igyekeztek a megye hatáskörét gyengíteni, de a kilencvenes évek első felében ad hoc módon kezdeményezett területfejlesztési programok esetenként mégis megyei szinten merültek fel. Ilyen eseti akciókra került sor az Antall-kormány idején, amikor a kormány kihelyezett üléseket tartott egyes elmaradott megyékben. Ezeken a kihelyezett üléseken a kormány elé terjesztették a megye helyzetét értékelő dokumentumot, intézkedési csomagot fogalmaztak meg, amely későbbi fejlesztési kormányhatározatok alapját képezte. Ezek a helyzetértékelő dokumentumok, intézkedési tervek sok megyében a későbbi stratégiai koncepciók alapját képezték.

Bár helyenként külső vállalkozók, tervezési kft.-k, sok helyen pedig az MTA RKK helyi szervezeteinek a neve fémjelezte az egyes megyei területfejlesztési stratégiák dokumentumait, a stratégia kidolgozásával megbízott MTT-k széles társadalmi, gazdasági körrel konzultálva alakították ki koncepciójukat. A stratégiák kidolgozásában nem csupán az egyes települések, illetve önkormányzati társulások képviselöi vettek részt, hanem - kétféle elvet és elemzési szempontot összehangol$\mathrm{va}-\mathrm{a}$ területi munkacsoportok mellett ágazati munkacsoportokat is kialakítottak. A területi munkacsoportokban ugyanakkor, esetenként, a jelentös helyi foglalkoztatást biztosító vállalatok képviselői is helyet kaptak, akik ágazati fejlesztési elképzeléseiket fogalmazták meg. Az ágazati munkacsoportok szereplői a különböző szakmai kamarák, a helyi oktatási, képzési intézmények illetve az ágazati irányítás egyes képviselöi (pl. Munkaügyi Központok, Környezetvédelmi Hivatalok) voltak, továbbá akár területi, akár ágazati munkacsoportba sorolva számos civil szervezet (alapítványok, egyesületek) képviselője.

Magát a stratégiai koncepciót számos részterületet érintő funkcionális (agrár, ipar, infrastruktúra, marketing, képzés stb.) és területi (kistérségi) fejlesztési koncepció összehangolásával alakították ki. Ellentétben a nyolcvanas évek végi, kilencvenes évek eleji, területi hatásokkal is járó iparfejlesztési, válságkezelési elképzelésekkel, ezekben a koncepciókban az ágazati fejlesztési elképzelések háttérbe szorultak. A megfogalmazott fejlesztési stratégiák a szerkezet-átalakításra, a vállalkozások müködési feltételeinek, versenyképességének javítására, az infrastruktúra-fejlesztésre, a humán erőforrások fejlesztésére, az elmaradott térségek felzárkóztatására, a környezetvédelemre és a regionális kohézió erősítésére helyezik a hangsúlyt. Az 
egyetlen ágazat, amely több megyei fejlesztési koncepcióban is mint ágazat szerepel a fejlesztési prioritások között, az élelmiszergazdaság.

A területfejlesztés módszertanának és gyakorlatának kialakulásában az első lépés az intézményrendszer létrehozása volt. A már létrejött MTT-k közremüködésével kistérségi gazdaságfejlesztési irodákat hoztak létre. Az MTT-k szakmacsoportonkénti bizottságokat alakítottak, akik a közbeszerzési pályázatokon nyertes, a megyei stratégia kidolgozásáért felelős vállalkozókkal konzultáltak, munkájukat véleményezték és koordinálták.

A legtöbb megyében eddig még csak az 1996-os törvény által előirt stratégiai koncepció készült el, amely helyzetképet tár fel, megfogalmazza a megye erósségeit, gyengeségeit, lehetőségeit és a külső veszélyforrásokat (SWOT analízis), jövőképet ad, és meghatározza a fö fejlesztési irảnyokat, a stratégiai prioritásokat. Ezt nevezzük feladatkijelölő stratégiának. A stratégiai koncepciót konkretizáló, annak konkrét tartalmat adó programcsomagok, projektek sok helyen csak most készülnek. A pályáztatás alapját tehát eddig még nem az EU-konform, komplex programok képezték, de a pályázatok elbírálásakor már a fejlesztési elveket, prioritásokat megfogalmazó stratégiai koncepciót veszik figyelembe.

A koncepció kialakitásán túlmenően, a stratégiáknak tartalmat adó konkrét programok kialakításában, illetve megvalósításában elörelépés csak néhány megyében történt. A többség csak az elfogadott fejlesztési koncepció dokumentumával rendelkezik, amelyet vagy felhasználnak koncepcionálisan a decentralizált területfejlesztési eszközök pályáztatásakor, vagy nem. Van, ahol a megújult összetételủ MTT-k új tagjai nem itélik megfelelőnek az előd időszakában készült koncepciót és azt még elviekben sem használják, van, ahol „vitrinben tartják”, hogy kéznél legyen, ha be kell mutatni, hogy a kiírt és elfogadott pályázatok a megyei fejlesztési koncepcióba illeszkednek.

Elórébb tart az a három kiemelt megye (BAZ, Nógrád és Szabolcs-SzatmárBereg), amelyek GDP-je az országos átlag 70\%-át nem érte el. Ezek a megyék (2000-töl Békés és Somogy megye is) kiemelt fejlesztési forrásokban részesültek. Esetükben ez nem csupán a magasabb összeg (és esetenként a kapcsolódó PHAREforrások) miatt volt kedvező, hanem mert ezek a megyék a források felhasználásában a többi megyénél nagyobb fokú önállóságot élveztek. E megyék a többi megyénél korábban töltötték meg konkrét tartalommal fejlesztési koncepcióikat, a kilencvenes évek közepétöl kezdve három-négy éves felzárkóztatási programokat készítettek, amelyeket a központi alapokból külön összegekkel támogatott a kormányzat.

\section{A Megyei Területfejlesztési Tanácsok szerepe}

A magyarországi regionális politikát értékelve az EU országjelentése a pozitívumok között említi az intézményrendszer kialakításában elért eredményeket (Szaló 1999). A területfejlesztésért, a stratégia kimunkálásáért és a megvalósítás menedzseléséért felelös intézmények valóban létrejöttek, ám az intézmények működését meg- 
határozó szabályozórendszer még sok kívánnivalót hagy maga után. Az MTT-k múködése a mesebeli okos lány ajándékára hasonlit: müködnek is, meg nem is. Múködésük jogállása kevéssé tisztázott, hiszen az MTT-k ötvözik magukban az állami, önkormányzati, gazdálkodói, társadalmi és a civil szervezetek működési elemeit. Az MTT-k költségvetési intézmények, ugyanakkor nem minösíthetök közigazgatási szervnek (Gyarmathy 1998; Pfeil 1999). Az MTT egyfajta tisztázatlan hatáskörü, fiktív önkormányzat. Munkaszervezetei eredetileg a megyei önkormányzatok bázisán jöttek létre, de idövel kiváltak, telephelyileg is elkülönültek. Amellett, hogy a törvény szükségtelen párhuzamosságot hozott létre a területfejlesztési és az önkormányzati intézményrendszerben, az önállóságnak sok hátulütöje van, hiszen hagyományosan a megyei önkormányzatok rendelkeznek információkkal, az ő szervezetükben müködik a Területi Információs Rendszer (a megyei föjegyző hatảskörében). Az információs rendszer létrehozásán és állandó frissítésén tủlmenően térségi területrendezési (és az ehhez kapcsolatos tervezési) és idegenforgalmi feladatok, továbbá az épített és a természeti környezet védelme tartoznak a megyei önkormányzatok feladatkörébe. Bár az önkormányzatok és az MTT-k feladatkör-meghatározásaiban sok az átfedés, az intézményi elkülönülés következtében a megyei önkormányzatok nagy részénél mára félig-meddig elsorvadt a fejlesztés, mint szemlélet és feladatkör.

A törvény az MTT-k és az egyéb helyi (települési, megyei) önkormányzatok mellérendeltségi viszonyát fogalmazza meg. Az önkormányzatok így nem tartoznak adatszolgáltatási kötelezettséggel az MTT-nek. Így fordulhat elö, hogy sok helyen a területfejlesztési stratégia kidolgozásáért felelös szerv nem jut hozzá azokhoz az alapvetô információkhoz, amelyek az éves pályáztatási rendszer kialakításakor nélkülözhetetlenek.

Az MTT-k mozgástere minimális: kormányrendelet írja elő a pályázatok feltételeit, a pályázati célokat, a támogatási formákat (visszatérítendö, vissza nem térítendö) és azok megoszlását. A rendelkezésre álló keretösszegeket központilag határozzák meg, sem a megyei fejlesztési stratégia minősége, sem a beérkezett helyi pályázatok minősége nem befolyásolja érdemben a keretösszegek nagyságát. A rendszer logikája fordítva működik: nem a szerint a megközelítés szerint, hogy van egy prioritási kör, vannak célcsoportok, és a kettöt megfeleltetik egymásnak. Ehelyett a megye területén múködő önkormányzatok és egyéb gazdasági és civil szervezetek mindig arra pályáznak, amire van kijelölt keret, és nem arra, amire szükség lenne.

Az elözỏ fejezetben emlitett hiányosság, nevezetesen, hogy a stratégiai koncepció sok helyen csak elvi síkon jelenik meg a pályázatokban, nagyrészt arra vezethetö vissza, hogy az MTT-k a kormányrendeletben listázott fejlesztési célok struktúráján és prioritási sorrendjén sem változtathatnak. Az utóbbi években a közvetlen kormányzati beavatkozás fokozódott ezen a téren, a rendeletben elöírt, nem módosítható célok száma nött, a megyei sajátosságok figyelembevételére egyre kevésbé nyílik lehetöség. 
Egyetlen példa arra vonatkozólag, hogy a helyi sajátosságok ismerete miért létkérdés a fejlesztési prioritások meghatározásánál, a fejlesztési döntések meghozatalakor. Amennyiben az MTT-k a fejlesztési prioritások kialakításában nagyobb döntési szabadsággal rendelkeznének, kevésbé fordulhatna elö, hogy egyes elmaradott települések a statisztika torzítása miatt kiessenek a kiemelt támogatásra jogosultak köréböl. Sok, igen elmaradott település azért nem kerül bele a normatív mutatószámrendszer alapján meghatározott, kiemelten fejlesztendők közé, mert egy gazdasági erőcentrum vonzáskörzetében fekszik. İgy a térsége nem tartozik a kiemelten fejlesztendő elmaradott térségek közé. A gazdasági erőcentrum (nagyváros) ugyanakkor nem gyakorol rá jótékony hatást, mert a település és a város közötti összeköttetés nincs megoldva. A település mégsem pályázhat, pl. útfejlesztésre fordítható kiemelt támogatásra, hiszen az a statisztikai térség, amelybe tartozik, a nagyváros jelenléte miatt nem minösül elmaradottnak.

Az MTT-k természetesen tisztában vannak ezekkel, a statisztika torzításából fakadó problémákkal, mivel azonban döntési szabadságuk minimális, nem csoportosíthatják át a rendelkezésükre álló összegeket.

A három (ma már öt) kiemelt megye területfejlesztési intézményei a fenti eljárásrendnél nagyobb fokú önállóságot élveznek. Számukra nincs meghatározva olyan mereven a pályázati célrendszer, mint a megyék többsége számára. Esetükben a célok kijelölése épp fordítva müködik, nem a kormányrendeletben listázott célokat fogalmazzák meg a pályázataikban, hanem ők határozzák meg a fejlesztési programjukat, ezt fogadja el a szakminisztérium és a kormányzat. A pályázati célok és a megye részére rendelkezésre álló decentralizált keretek közötti mozgásról is a többieknél némileg szabadabban dönthetnek. Egy nem kiemelt megyében például az egyik pályázó egy elnyert munkahelyteremtési pályázatot szeretett volna befektetés-ösztönzési, pontosabban, beszállítói rendszerfejlesztési programmá átalakítani, mert változott a cég koncepciója, és az adott beruházást már nem házon belül akarta megvalósítani, hanem beszállítójával szoros együttmüködésben, a beszállítónál. $\mathrm{Az}$ adott megyében a pályázónak erre nem volt lehetösége, míg a kiemelt megyékben, ahol a forrásokat, ha nem is mindig EU-konform módon, de integráltan kezelik, lett volna.

A nem kiemelt megyékben müködő MTT-k az elöre meghatározott eljárási rendben kiírják, majd lebonyolítják a pályázatokat, értékelik, szürik, és végül meghozzák a döntést, hogy a központilag elöirt feltételeknek megfelelő pályázatok közül melyeket támogatják. A rengeteg kötöttséget, a minimális mozgásteret talán még lehetne azzal magyarázni, hogy a kormányzat ilyen módon kívánja biztosítani, hogy a megyei szintü fejlesztések a (most készülö) nemzeti fejlesztési programban megfogalmazott makrocéloknak megfeleljenek. Nehezebben találunk magyarázatot arra a jelenségre, hogy az MTT-k csupán mint adminisztratív intézmények müködnek, hiányzik a területfejlesztés stratégiai jellege.

A területfejlesztés intézményei ,belefulladnak” az adminisztratív teendőkbe, stratégiaalkotásra nem jut idő. Megyénként legalább háromféle pályázati rendszer 
múködik. A kiemelt megyékben az integrált forrásokra kiirt pạlyázatokkal együtt a pályázati rendszerek száma akár a nyolcat is elérheti, ezekre legalább 250-300, de akár 1000 pályázat is érkezhet évente. Ennek a hatalmas mennyiségú anyagnak az adminisztratív befogadása önmagában rengeteg idöt igényel, a szakmai minősités, az értékelési mechanizmus menedzselése kitölti a munkatársak idejét, leköti energiáját.

Az MTT-k stratégiai szerepe nem egyszerü szervezetbővitéssel erősödhetne, hanem a szervezeti funkciók egyértelmű megjelenítésével, a funkciók, a szervezet tagolásával történő elhatárolásával. Az adminisztratív részleg mellett szükség lenne külön monitoring-részlegre ${ }^{6}$ és stratégia-alkotó részlegre. Ez utóbbi nem csupán a stratégiai koncepciót és a programot készíti el, hanem a stratégia megvalósításának menetét is nyomon követi, és szükség esetén módosítja a prioritásokat.

A stratégiai jelleg hiányára utal az a tény is, hogy a területfejlesztés adminisztratív teendőivel megbízott MTT-k a decentralizált területfejlesztési eszközökkel nem gazdálkodhatnak. Az MTT-k a pályázatokat lebonyolítják, értékelik, a döntéseket meghozzák, de a pályázati pénzt a Magyar Államkincstár kezeli és utalja át. A Kincstár tehát nem az MTT-k számlájára utalja át az adott évben megítélt keretösszeget: amint finanszírozásra kerül sor, az MTT-ket kiiktatják a rendszerből. A kizárólag adminisztratív szerepet betöltő MTT-k és a fejlesztési feladatokat szintén ellátó, de a normatív alapon megítélt fejlesztési pénzekkel és egyéb bevételeikkel önállóan gazdálkodó helyi önkormányzatok között ez a legfontosabb különbség.

Az MTT-k munkaszervezetei rendszeres értékeléseket készítenek egy-egy komplex program megvalósulásának elörehaladásáról (erre azokban a megyékben került sor, ahol egyáltalán volt lehetőség komplex fejlesztési programokat indítani, pl. PHARE-forrásból). A hatóságok ugyanakkor értékelés címén nem stratégiai jellegủ beszámolókat vártak el, amelyek rögzítették azokat a csomópontokat, ahol elörelépés történt, vagy azokat a szűk keresztmetszeteket, amelyek a további fejlesztést akadályozzák, illetve azokat a területeket, ahol belátható idön és ráfordításösszegen belül konkrét programpontok megvalósitásával áttörést, minöségi javulást érhetnek el. A hatóságok puszta pénzügyi elszámolást kértek. Az éves értékelések így többségében abból álltak, hogy az „értékelök” listázták a bevételeket, a kiadásokat és a megkezdett beruházásokat, projekteket.

Az adminisztratív szerepkör mellett az MTT-k inkább politikai lobbi, semmint stratégiai funkciót látnak el. A lobbizás azonban, szerencsétlen módon, nem pótlólagos külső forrásokért, hanem a szervezeten belül folyik annak érdekében, hogy a meglévő keretösszegböl az egyes önkormányzatok, kistérségek, kistérségi társulások képviselői minél többet szerezzenek meg saját maguknak. A Megyei Területfejlesztési Tanácsokba delegált térségi társulások képviselöinek eredményességét egyértelműen annak fényében ítélik meg, hogy ki mekkora támogatást tudott a saját térségének kiszakítani a rendelkezésre álló keretböl.

Akadt példa sikeres „külső” lobbitevékenységre is. A Baranya megyei MTT képviselöi például súlyt helyeztek arra, hogy országgyülési képviselőkkel, illetve az Országos Területfejlesztési Központ képviselöivel megismertessék regionális fej- 
lesztési terveiket, a térségi, határokon átnyúló kapcsolataik kiépítése során szerzett információkat. Sikeres kommunikációjuk eredményeképpen elérték, hogy olyan, jelentős ráforditás-igényü fejlesztési tervek is bekerüljenek az országos közlekedésfejlesztési koncepcióba, mint amilyen Baranya megye közlekedési elzártságának oldására szolgáló autópálya- és egyéb úthálózat-építés.

Az MTT elnöke, aki egyben a megyei közgyủlés elnöke is, elvileg közbenjárhat a megyei fejlesztési célok megvalósítása érdekében az országos szerveknél. A legutóbbi, 1999-es törvénymódosítás óta azonban inkább fordított a helyzet, az MTT-k az országos politikai akarat leképeződéseként müködnek. Összetételük megváltozott: ma már nem a kistérségek képviselöi alkotják az MTT tagságának zömét (a jelenleg érvényes rendelkezés értelmében összesen három kistérség képviselöi foglalhatnak helyet a döntési testületben), megszünt a kamarai illetve a munkáltatói, munkavállalói oldal képviselete, vagyis a gazdasági szféra képviselöi kikerültek a döntési körböl. Az önkormányzati oldal (kistérségek képviselöi) helyett a kormányzat képviselői kerültek többségbe, ami nem felel meg az EU-konform területfejlesztés követelményének, hiszen ez utóbbi elöírása szerint a regionális területfejlesztési intézményrendszer élén közvetlenül választott testületeknek kell állniuk. A meginterjúvolt területfejlesztéssel foglalkozó szakemberek szerint regionális szinten még rosszabb a helyzet. Míg az MTT-k döntéshozó testületének többségét legalább „helyi, a megyei érdekeket szívén viselö emberek alkotják”, az RFT-k 20 fös döntési testületében már valóban a régióhoz nem kötödö, kizárólag a központi akaratot megjelenitő kormánydelegáltak (az egyes minisztériumok képviselői) vannak többségben.

A kérdés, miszerint helyi emberrel vagy „messziröl jött”, a fövárosból delegált tanácstaggal lehet-e eredményesebben együttmüködni, a régió érdekeit jobban érvényesíteni, az 1999-es területfejlesztési törvénymódositást követően merült fel újra. Ekkor ismét megváltozott az RFT-k összetétele, ami a szakértőket rádöbbentette arra, hogy a „helyi ember” a messziröl delegált képviselővel szemben nem mindig, eleve és feltétlenül ideális jelölt. A törvénymódosítást követően a korábbi minisztériumi delegáltak státuszát visszavonták, és az egyes minisztériumok képviseletében csupa „helyi embert” jelöltek a tanácsokba. Korábban a minisztériumok delegáltjainak többsége az adott régióért felelös minisztériumi föosztályvezető volt, aki tisztában volt a minisztérium álláspontjával, fejlesztési koncepciójával csakúgy, mint a régió helyzetével, terveivel. Kiterjedt kapcsolatrendszere révén képes volt kétirányú kommunikációt megvalósítani: a régió felé közvetítette a minisztérium álláspontját, tájékoztatást adott a minisztérium koncepciójáról és annak módosulásairól, ugyanakkor közvetítette a régió véleményét, ellenjavaslatait a minisztérium felé. Az újonnan delegált minisztériumi képviselök partikuláris ügyekre szakosodott „helyi emberek” voltak, egy megyei jogú város stratégiai irodájának képviselője, a meg̀yei Közlekedési Felügyelet egyik osztályvezetője, a megyei közgyülés ügyrendi bizottságának tagja, egy városfejlesztési iroda alkalmazottja stb. A ,helyi emberek" döntő többsége nemcsak a régió ügyeiről nem rendelkezett a korábbi 
jelöltekhez hasonló, átfogó szakmai ismeretekkel, de minisztériumi kapcsolatokkal sem. „Helyi” mivoltuk következtében nem ismerték annak a minisztériumnak a koncepcióját, amelyet megjeleníteni, közvetíteni voltak hivatottak. Személyükkel azonban módosult, homogénebbé vált az RFT-k politikai összetétele, amely immár nem a minisztériumok - és így a parlament - politikai struktúráját képezte le, hanem a nagyobbik kormánypárt érdekeit jelenítette meg. Mivel ezek a nagyobbik kormánypárthoz kötődỏ delegáltak pártutasításnak megfelelően szavaztak az egyes szakmai kérdésekben, a tanácsok összetételének módosítása voltaképpen a kormánykoalíción belüli hatalmi pozíciók átrendezését szolgálta. Bár a tanácsok tagjainak többsége „helyi ember” volt, a konkrét szavazások alkalmával a régió érdeke még kevésbé jelent meg, mint a korábbi összetételü tanácsok döntéshozatalakor. ${ }^{7}$

\section{Döntés elötti vita a támogatásokról}

A támogatási döntéseket megelőző viták visszatérö kérdése, hogy egy-két, az éves keretet gyakorlatilag kimeríto „,nagy pályázatot” támogassanak-e, kizárva ilyen módon a sok, kis összegủ támogatásért folyamodó pályázót, vagy inkább ez utóbbiakat támogassák, hiszen a multinacionális vállalatok máshonnan is megszerezhetik a beruházáshoz szükséges forrásokat. A multinacionális vállalatok támogatása mellett szóló érv az általuk kezdeményezett beruházások tovagyürúző, multiplikátor hatása, a nagyszámú munkahely teremtése, az adott fejlesztéshez kapcsolódó egyéb beruházások. A KKV-k támogatása mellett szóló érv az ö támogatásuk kiemelt gazdaságpolitikai jelentősége. A KKV-k révén kapcsolódhatnak be a multik a gazdaság vérkeringésébe, tevékenységük révén nő a termelés hazai hozzáadott értéke és munkahelyteremtő képességük is jelentős.

A kérdést többféleképpen közelítették meg az egyes önkormányzatok. Az egyik lehetőség az volt, hogy az MTT-k szimbolikus összegekkel támogatják a térségükben működő multinacionális cégek fejlesztéseit. Egy 1,5 milliárd forintos fejlesztéshez nyújtott 3 millió forintos vissza nem térítendő támogatás pusztán abból a szempontból jelent többet szimbolikus gesztusnál, hogy sok esetben a központi támogatás odaítélésének egyik feltétele a megyei támogatás elnyerése. A 3 millió forintos támogatással a cég pusztán azt dokumentálja a központi alapok kezelöi felé, hogy a helyi MTT is támogatja a fejlesztést.

Ugyanakkor, számos példa akadt arra is, hogy ezek a cégek még a szimbolikusnál nagyobb arányú (a kért összeg 10-20\%-a) támogatást is elutasítottak, mondván, nem gesztusokra van szükség, legyen egyértelmü, hogy támogatja-e öket a kormányzat, vagy sem. A kért összegnél jóval kisebb támogatásról szóló értesítés új alkufolyamatot indított el, a pályázók igyekeztek a pályázatban vállalt, újonnan létrehozott munkahelyek számát csökkenteni.

A másik megoldási javaslat értelmében az MTT megbízott egy helyi pénzintézetet, hogy mérje fel a pályázók hitelképességét (Borsod-Abaúj-Zemplén megyében például a Rákóczi Bankot), és a hitelképes pályázókkal tárgyalni kezdett a támogatás egy részének hitellel történő kiváltásáról. Az MTT ajánlata ilyen esetekben úgy 
hangzott, hogy a kért összeg viszonylag kis részét tudják vissza nem térítendő támogatás formájában nyújtani, a fennmaradó részre azonban kedvezményes kamatozású hitelt nyújtanak. Volt, ahol a tárgyalások sikerre vezettek, de arra is akadt példa, hogy egy multinacionális cég (az egri ZF) a Borsod-Abaúj-Zemplén megyében bevezetetthez hasonló konstrukciót ${ }^{8}$ (vissza nem térítendö támogatás helyett kedvezményes hitel) elutasította, és beruházásához (új termék gyártásának Magyarországra telepítése, illetve a gyártáshoz kapcsolódó kutatás-fejlesztés áttelepítése) más országban keres telephelyet.

A harmadik lehetőség az volt, hogy a keretböl egy adott összeget elkülönítettek, amelyből kizárólag kis- és középvállalati pályázatokat lehetett támogatni. Ezt a KKV pályázati keretösszeget külön hirdették meg. A fennmaradó részre multik és KKV-k egyaránt pályázhattak, így „kevésbé volt rossz a lelkiismeretük”, ha a fennmaradó részből nagy összegü támogatást szavaztak meg.

Volt, ahol megszabták a multinacionális vállalatoknak nyújtható támogatás felső határát. „Meghatározott értékủ jogos támogatási igény felett - határolta be az egyik megye a támogatandók körét - a megye egy tételben maximum 100 millió forintos támogatást nyújthat."

Az ötödik megközelítési módszer szerint az MTT-k nem úgy próbáltak egyensúlyt teremteni a multik és a KKV-k, vagyis a sok kisösszegü és a néhány nagyösszegủ támogatás odaítélése között, hogy arányosan csökkentették a kért összeghez képest a megítélt támogatási kereteket, hanem megpróbáltak megállapodásra jutni a szereplőkkel valamiféle elvi eljárási rendben. Megállapodtak abban, hogy egyik évben egy-két multinacionális cég nagyösszegü támogatási igényét elégítik ki, amely a rendelkezésre álló keretet gyakorlatilag kimeríti. A KKV-kat ugyanakkor arra bíztatták, hogy a következö évben is pályázzanak, mert a következő évben csak KKV-pályázatokat fognak támogatni. Ez a kiegyensúlyozási módszer akkor volt müködőképes, ha a szereplök hitelesnek találták a támogatási rendszert, megbiztak abban, hogy a következö évben is hasonló nagyságú támogatási összegröl döntenek, vagyis a keretösszeg rendelkezésre áll, a döntési elvek átláthatóak. A rendszer első éveiben a szereplök általában a „lehetőleg a maximumot azonnal kiszakítani" stratégiáját követték - ekkor nem volt más lehetőség, csak a kért összegek arányos csökkentése az adott évben szétosztható keretösszeg határáig. Kooperációra egy-két év elteltével lettek képesek a szereplők. ${ }^{9}$

Az interjúk tapasztalatai szerint a fenti elvi jellegủ kérdést az egyes tanácsok képviselői vérmérsékletüktöl függően, saját hatáskörükben döntötték el. Volt, aki kijelentette, megyéjükben szó nem lehet arról, hogy multinacionális cégeket támogassanak, az ő befektetés-ösztönzési keretükből olyan csekély támogatásra futja, amely egy multi számára fel sem használható valamilyen konkrét, körülhatárolható célra, míg ugyanez az összeg egy-két kisvállalkozó számára az indulás, vagy a növekedés megalapozásául szolgálhat. Ehhez az elvi döntéshez az vezetett, hogy felismerték, az általuk nyújtható támogatás mennyire eltörpül egy multi beruházásának összértékéhez képest. Arra a következtetésre jutottak, hogy a multi telephelydöntését ez a 
jelentéktelen összeg semmiképpen sem befolyásolhatja. A konkrét példa, amely ezt a felismerést szülte, egy, a megyébe települő nagykereskedelmi vállalkozás támogatása volt. A cégnek 10 millió forintos támogatást szavaztak meg. A multi 150 millió forintért vásárolta meg a telket, és ezt meghaladó összeget fordított az építési munkálatokra. A meginterjúvolt MTT-képviselö szerint rossz döntés volt a multi támogatása - az ilyen nagyságrendủ beruházást végző multi valószínüleg kevésbé szorult rá a támogatásra, mint sok, a megyében tevékenykedő kis- és középvállalat.

A multik „támogatását” több megyében úgy oldották meg, hogy a vállalat közvetlen támogatása helyett a saját fogadókészségüket (tökeabszorpciós képességüket) igyekezték javítani, a müködőtőke-befektetők letelepedési feltételeit igyekezték minél vonzóbbá tenni. A decentralizált fejlesztési eszközöket ipari parkok létrehozására fordították, ahol a megfelelő infrastrukturális feltételek biztosítása mellett munkacsoportokat hoztak létre egy-egy multi letelepedéséhez, telephelylétesítéséhez szükséges bürokratikus ügyintézés meggyorsítására.

E szerint a filozófia szerint a multik telephely-megfontolásait amúgy is kormányszinten lehet csak befolyásolni, ha egyáltalán lehet. A kormány orientálhatja a multikat azzal, hogy jelentősebb központi támogatást ígér, amennyiben a cég vállalja, hogy elmaradott térségben hozza létre a telephelyét. A helyi MTT-k feladata a fogadókészség biztosítása, potenciális befektetők számára a közművesített, infrastruktúrával ellátott területek előkészítése, a befektetök tájékoztatása a helyi feltételekröl (az utak állapotáról, a munkanélküliség mutatóiról, a képzettség helyi szintjéröl, a térségben müködő egyetemekről, föiskolákról és nyelvi képzést biztosító intézményekröl). A települések, önkormányzatok felkészullése azt jelenti, hogy az önkormányzatok kidolgozzák a befektetés-ösztönzés helyi normatíváit, nevezetesen, hogy melyik önkormányzat milyen feltételekkel mennyi adókedvezményt ad, milyen áron adják bérbe, vagy értékesítik a befektetők számára előkészített területeket - mindezt lehetőleg differenciáltan, a meghonosítani kívánt tevékenységtől függően.

Más megyék nem kizárólag a kormányszintủ orientálásban reménykedtek, hanem komoly befektetés-ösztönzési programokat alakítottak ki, és hajtottak végre a potenciális befektetők megyéjükbe vonzása érdekében. Szabolcs-Szatmár-Bereg megyében például a megyei arculatformálási programokon - brosúrák, CD ROM kiadásán - túlmenően súlyt helyeztek a megye promóciójára is. Nemzetközi sajtótájékoztatón mutatták be anyagaikat (pl. a megye 50 legjelentősebb vállalkozását bemutató kiadványt, tájékoztató anyagokat a megyei befektetési lehetőségekröl). A sajtótájékoztatón részt vettek a megyében müködő fontosabb gazdálkodó szervek képviselői is, bemutatták termékeiket. Az általános promóciót azonban nem követte a célzott promóció szakasza, a potenciális befektetök célcsoportjának azonositására és személyes megkeresésére már nem került sor. Az egyes promóciós akciók így egyszeri alkalmaknak bizonyultak, hatásukat lehetetlen volt felmérni.

A felemás illetve mérhetetlen eredmények ellenére nem lehet eléggé hangsúlyozni a Szabolcs-Szatmár-Bereg megyei kezdeményezés jelentöségét. A befektetés- 
ösztönzés eszköztárából ugyanis, a hazai gyakorlatban, az egy-két PHAREprogrammegyét leszámítva ma még gyakorlatilag hiányzik a promóció. A befektetés-ösztönzési eszközök infrastruktúra-fejlesztésre, ipari telephelyek biztosítására, illetve pénzügyi támogatásra korlátozódnak. A promóció hiánya ahhoz vezet, hogy az ipari telephelyek kialakítására és az ezekhez kapcsolódó infrastrukturális fejlesztésekre szánt összegek, „testreszabás” híján, sokszor „légüres térbe kerülnek”; a mezögazdasági müvelésböl kivont, infrastruktúrával részben felszerelt ipari parkok üresen állnak.

A regionális szolgáltatások között megjelent, de még nem megfelelően müködik az információ-szolgáltatás. A befektetés-ösztönzés eszköztárán belül, egyelöre csak néhány megye stratégiai koncepciójában (kívánságlistáján, de nem a gyakorlatban megvalósított programjaiban) szerepel olyan típusú közjavak létrehozása és müködtetése, mint az innovációs központok, $\mathrm{K}+\mathrm{F}$ intézmények, illetve a szintén a közjavak közé sorolható befektetöi és beszállítói konferenciák szervezése.

A multik támogatását elutasító, a KKV-k támogatását kiemelten kezelő megyék között nagyfokú eltérés mutatkozott abban, hogy az induló vagy a növekvö vállalkozásokat támogatják-e inkább. Míg egyes megyékben nem tettek különbséget, mások képviselöi annak a meggyőzödésüknek adtak hangot, hogy az induló vállalkozások támogatását jobban szolgálja az MVA mikrohitel-programja, a decentralizált keretekből az MTT a növekedni, beruházni kívánó vállalkozásoknak ad inkább támogatást. Induló vállalkozásoknál, érvelt a képviselö, nincs még megfelelö vagyoni fedezet, kétséges, hogy fennmarad-e a vállalkozás.

Más megyében is alapvetỏen egyetértettek ezzel az elvvel, de differenciáltan kezelték a pályázatokat: elmaradott térségekben könnyebben támogattak induló vállalkozásokat is.

A kereskedelem-fejlesztést általában kizárták a támogatott tevékenységek köréből: elmaradott térségekben esetenként támogattak kereskedelem-fejlesztési pályázatokat is, de munkahelyteremtés címén leginkább feldolgozóipari, illetve mezögazdasági vállalkozások fejlesztéseihez járultak hozzá. A tapasztalatok azt mutatják, hogy bár a tercier szektor mind foglalkozatási, mind értékteremtési szempontból átvette a vezető szerepet, és tovább növeli részarányát (a foglalkoztatottak számán és a GDP-n belül), Magyarországon a területfejlesztési filozófia és stratégia még mindig alapvetően ipari alapú, nem szolgáltatás-fejlesztésre épül (Kiss 1998).

\section{Forráskoordináció}

Egy-egy fejlesztést saját forrás mellett igen nehéz egyetlen külső forrásból megvalósítani. A forráskoordináció (társfinanszírozás), vagyis különféle külső források összehangolt igénybevétele egy-egy komplex program megvalósítása érdekében egyébként is az EU-konformitás egyik alapkövetelménye. A forráskoordinációt igencsak megnehezíti, hogy a támogatási rendszerben élesen elkülönül a területi és az ágazati elv. A decentralizált területfejlesztési, területi kiegyenlítési keretek és az ágazati pénzelosztó rendszerek, elkülönített állami, funkcionális alapok felhaszná- 
lását eddig rendkívül nehéz volt összehangolni, vagyis több forrásból meríteni egyegy komplex fejlesztési program megvalósítása érdekében. Az egyes tárcák még ma sem írják ki egy időben a pályázatokat, sőt a kiírt célok közötti összhang sem valósul meg.

A forráskoordináció a legtöbb MTT szerint a pályázók feladata. E szerint az értelmezés szerint a komplex projektek finanszírozási bázisát nem intézményesen kell megteremteni, hanem a pályázóknak kell felkutatniuk a létező forrásokat, meg kell találniuk a különböző intézmények eltérö céljainak megfelelö „hívószavakat”, pályázati kulcsszavakat, és annyi pályázatot kell beadniuk, hogy nem csupán a beruházás megkezdése, de a befejezése is biztosítva legyen. (Ez utóbbi gyakori probléma, sokszor előfordul, hogy a beruházás megkezdődik, elfogy a pénz, és megkezdett beruházásra már szinte lehetetlen pótlólagos támogatást igényelni.)

Tanulságos, ahogy az egyik MTT képviselöje megfogalmazta a követendő példát: „Egy pályázó halastavat akart kialakítani maga és családja fenntartására. Támogatásért pályázott az MTT-hez és meghatározott összeget el is nyert. Pályázatot adott be továbbá az FVM-hez, ahol szintén nyert. Támogatást kapott a Víziigyi Alaptól is. Legvégül a Cigány Önkormányzathoz fordult, ahonnan szintén jelentősebb összegü támogatást nyert."

A pályázó ügyessége lebilincselő, ám a forráskoorđináció megvalósítása nem kizárólag a pályázó feladata, hanem intézményes garanciák és jól kialakított támogatási szerkezet révén kellene, hogy megvalósuljon.

Egyes vállalkozó szellemü, jó központi kapcsolatokkal rendelkező MTT-k nem csupán a lehetséges forrásokról nyújtanak információt, hanem közbenjárnak a központi pénzalapokat kezelö intézményeknél, hogy egy-egy fontosnak tartott helyi pályázat ne csupán megyei, hanem különböző központi támogatásokból is részesüljön. Másutt ugyanezt a pályázóra bízzák, hiszen „a megye úgysem befolyásolhatja a központi pénzek allokációját”. Igaz, amennyiben egy pályázó bármilyen központi célelöirányzathoz pályázatot nyújt be, a központi pénzalap képviselöi kikérik az MTT véleményét, ezt azonban a megyék többsége abszolút formálisnak tartja. Mivel a megyéktől nem a pályázatok rangsorolását kérik (kivéve az Útalap és a Környezetvédelmi Alap pályázatainál), hanem puszta értékelést, illetve annak megjelölését, hogy az MTT mekkora összeggel támogatja az adott pályázatot, a központi đöntés gyakran nem esik egybe az MTT által helyesnek tartott rangsorral. Ilyenkor fordulnak elö olyan, az intézmények közötti sértettséget tovább fokozó esetek, hogy bár a megye fontosnak ítél és támogat is bizonyos helyi pályázatokat, ezek a pályázók központi támogatás hiányában nem tudják megvalósítani beruházásukat, így a már megítélt megyei támogatásról is le kell mondaniuk. A törvény elvileg lehetővé teszi, hogy az MTT-k megállapodást kössenek a tárcák képviselöivel, a célelőirányzatok kezelöivel a támogatási elvek egységesítése, bizonyos projektek kiemelt kezelése érdekében, erre azonban - bár az egyik MTT képviselöje ezt egyszer kezdeményezte is - mindeddig nem került sor.

Intézményesített forrásintegrációra elöször Borsod-Abaúj-Zemplén megye integrált szerkezet-átalakítási programjának megvalósítása során került sor. A források integrálására a PHARE elöirásai miatt volt szükség, vagyis a kísérleti, komplex, 
PHARE által támogatott fejlesztési program megvalósulása érdekében, fel kellett adni az ágazati pénzosztás rendszerét. Kezdetben (1995-96) ezt úgy oldották meg, hogy az egyes minisztériumoktól a borsodi integrált szerkezet-átalakítási program megvalósítására elöre meghatározott keretösszegeket vontak el. A minisztériumok ezekre az összegekre már nem írhattak ki pályázatot, csak kizárólag a borsodi MTT. Ezzel a „forráskoordinációs módszerrel” két alapvető probléma volt. Az első az, hogy a PHARE nem tekintette integrált keretnek, emiatt nem járult hozzá a PHARE-támogatás folyósításához. A második probléma az volt, hogy a magyarországi forrásokat az MTT kizárólag a minisztériumi eljárási rend szerint pályáztathatta. Az MTT tehát nem gazdálkodhatott összevont keretösszeggel, hanem az elkészült stratégiai programból a minisztériumokkal egyeztetve azokat a programpontokat pályáztathatta meg, amelyek a minisztériumok célkitüzései között is szerepeltek (amelyeket a minisztériumok ,engedélyeztek”). Így történhetett, hogy bár a program nagy hangsúlyt helyezett a humán erőforrások fejlesztésére, ezeket a projekteket meg sem kezdhették, nem is pályáztathatták, mert a Múvelődési és Közoktatási Minisztériumtól nem vontak el pénzt a borsodi programra, a többi tárca pedig nem tartotta elfogadhatónak, hogy célrendszerükben nem szereplö célra használják fel „az ő pénzüket”, az általuk rendelkezésre bocsátott, tölük elvont keretösszeget.

Elöször 1997-ben tudtak ,igazi”, a PHARE által is elfogadott forráskoordinációt megvalósítani, amikor a Környezetvédelmi és Területfejlesztési Minisztérium költségvetésében egy összegben szerepeltették azt a keretösszeget, amelyet a különbözö minisztériumoktól erre a célra elvontak. Ezt a megoldást a PHARE is elfogadta, megkezdte a támogatás folyósítását, másrészt a borsodi MTT is „önállóan” (nem a minisztériumi eljárási rend szerint, hanem a támogatási struktúrát a saját célrendszere alapján összeállítva) gazdálkodhatott az egységesített keretösszeggel. Az MTT Ügynöksége mindazonáltal folytatta az egyeztetést a különböző tárcákkal. A szakmai kapcsolatok és a jó viszony megörzése érdekében tett gesztusok hasznosnak bizonyultak, hiszen az 1998-as közigazgatási átszervezések nyomán 2000-ben a borsodi fejlesztésre szánt források valószínủleg újra nem lesznek integrálva, ismét a tárcákkal kell egyezkedni.

Egy 1999-ben elnyert PHARE-pályázat keretében egy ír területfejlesztési szakértő felmérte a borsodi MTT tevékenységét. A felmérés egyebek mellett azt a célt is szolgálta, hogy olyan intézményi, szabályozási módosító javaslatokat fogalmazzanak meg, amelyek megvalósításával erösödik az MTT stratégiai jellege. A borsodi tapasztalatok alapján megfogalmazott következtetések, kritikák gyakorlatilag az összes MTT tevékenységére érvényesek. Az egyik legfontosabb hiányosságnak azt tartotta a szakértö, hogy a területfejlesztésért felelös szervezet nem képes arra, ami a hasonló EU-intézményeknél megszokott, mindennapi feladatok közé tartozik: az egyes helyi pályázatokhoz a társfinanszírozás forrásait felkutatni.

A stratégiákban szerepeltetett külső források, a megyei pályázatokban jelenleg csak papíron szerepelnek, ${ }^{10}$ megszerzésükkel nem foglalkozik senki. A fejlesztési 
programokban, amelyekkel az MTT-k hazai központi forrásokat pályáznak meg a tartalmi elöirásnak megfelelően, a költségtervben saját erő és külső források is szerepelnek. A külső források azonban csak az elvi lehetöségek listáját tartalmazzák egy-egy konkrét hozzárendelt összeggel. Külső forrásként meg van jelölve például, hogy létezik olyan PHARE-pályázat, amelynek célrendszerébe az adott megyei fejlesztési programban szereplő célkitüzés beletartozik. A megyei fejlesztési programban ezért az adott PHARE-pályázat és az abból remélt összeg szerepel külső forrásként - a társfinanszírozás követelményének megfelelỏen. A hazai központi források megítélését követően azonban a megyei intézmények már nem foglalkoznak azzal, hogy ezeket a papíron szereplö külső forrásokat meg is szerezzék. Nem alakult ki az a mechanizmus sem, hogy a pályázókat tanácsadással segítsék hozzá a külső forrás megszerzéséhez. A forráskoordináció szempontjából a legkedvezőbb az lenne, ha maga az MTT, illetve annak munkaszervezete intézményként fogná össze és koordinálná a külsö források megszerzését, intézményként venne részt PHARE-pályázatokon, és megszervezné a társfinanszírozást, a beérkezö pályázatok hazai és külső forrásokkal történő támogatását. Mindehhez természetesen arra volna szükség, hogy az MTT-k ugynökségein belül kullön részleg (osztály, szervezet) foglalkozzon a megyei fejlesztési stratégia alakitásával, a külső források megszerzésével és a megvalósítás nyomonkövetésével.

\section{A PHARE által támogatott területfejlesztési projektek tapasztalatai}

A PHARE-forrásokkal kapcsolatban a legtöbben a bürokratikus és hosszadalmas döntéshozatalt említették. Még csak nem is a PHARE-pályázatot elnyerni nehéz, állítják a procedúra ismeröi, hanem szerződést kötni, és a pénzhez hozzájutni. Rendkívül bürokratikus a PHARE kőzbeszerzési eljárás lebonyolítása, hiszen elöször a közbeszerzés dokumentációját kell összeállítani (PHARE-pályázatból finanszírozott beruházások esetén), a beruházást a PHARE helyi delegációjával (bizonyos összeghatár felett a brüsszeli bizottsággal) jóváhagyatni (mindez hónapokig tart), majd a jóváhagyás és a közbeszerzési eljárás lebonyolitását követően össze kell állítani a teljes közbeszerzési dokumentációt, és ezt a PHARE-ral ismét jóváhagyatni. Csak ezt követöen lehet a felhasználási szerződést megkötni, a pénzhez hozzájutni, és azt felhasználni. Mindennek előre megszabott határidőn belül kell megtörténnie, ami tapasztalatok szerint ritkán szokott a pályázóknak sikerülni. Ellenkezö esetben a megitélt támogatás elvész.

Gondot okoz, hogy a PHARE-szabályzat szerint kizárólag a szerződés megkötése után lehet a program végrehajtását megkezdeni, a pályázatot érintő pozitiv döntés ehhez nem elegendő. A magyar szabályok szerint azonban, a pályázat pozitív elbírálását követően még abban az évben hozzá kell látni a program végrehajtásához. Mivel a PHARE-forrásokhoz legtöbbször magyar társfinanszírozás is járul, a kétféle rendelkezés ütközik. Ilyen esetekben a pályázóknak a megítélt hazai, központi alapokból nyújtott támogatásokat saját erővel kellett kiváltaniuk, ha meg akarták 
kezdeni a projekteket. A saját erővel megkezdett beruházás megfelel az EUelöírásoknak, hiszen alapszabály, hogy először a saját eröt kell felhasználni. Saját eröként ugyanakkor ezek a pályázatok általában a magyar központi alapokból nyújtott támogatást értik és csak minimális mértékben a pályázó saját erőforrásait. Több esetben előfordult, hogy a hazai pályázók megkezdték saját erővel a beruházást, ugyanakkor a PHARE-szerződés megkötése olyannyira elhúzódott, hogy a beruházást nem lehetett folytatni, és a megítélt magyar forrásokat sem lehetett felhasználni.

Egyszerübb volt a képlet a nem kombinált (kizárólag PHARE-alapokból finanszírozott) pályázatoknál, ahol csak az elvi pozitiv döntést követő több éves huzavona okozott gondot a pályázóknak. A magyar és a PHARE-források kombinálásából, az eltérö felhasználási rendelkezésekből fakadó problémákat megoldaná, ha a decentralizált, területfejlesztésre szánt kereteket nem költségvetési tételként kezelnék, hanem „Alap"-ként. ${ }^{1]}$ Ez nem csak azt a problémát küszöbölné ki, hogy a területfejlesztésre szánt összegeket a tárgyévben feltétlenül fel kell használni, ellenkezö esetben az összeg elvész, hanem lehetőséget adna arra is, hogy a területfejlesztésre szánt összegeket szükség esetén egyéb célokra átcsoportosítsák.

További probléma, hogy a magyar társfinanszírozás magyar forrásokból megvalósított elemeire a magyarországi közbeszerzési eljárási rendben is le kell bonyolítani a pályáztatást. A dupla pályáztatás még mindig a könnyebbik megoldás, hiszen esetenként a különbözö forrásokból finanszírozott programelemek szétválaszthatók. Amennyiben a program egyes részterületei finanszírozási forrás szerint nem választhatók külön, a magyar félnek (FVM PHARE Iroda és az MTT Ügynöksége), illetve a PHARE képviselöinek (helyi delegáció, PHARE brüsszeli irodája) meg kell állapodniuk a pályáztatás (közbeszerzés) pontos lebonyolításában. Tapasztalatok szerint ez végképp nem müködik a megadott határidőn belül, így a Magyarország számára elvileg rendelkezésre álló PHARE-források nagy részét a magyar fél képtelen lehívni. ${ }^{12}$

A magyar adórendszer számára komoly gondot okozott a PHARE-forrásokra vonatkozó eltérő szabályozás. Mivel a PHARE rendszerében nem ismerik el az ÁFA-t, a PHARE-pályázatok elszámolásánál ezt a problémát meg kellett oldani. A vállalkozók számára ez csak könyveléstechnikai probléma volt, hiszen ök később visszaigényelték az ÁFA-t, de a nem ÁFA-alany önkormányzatok számára ez a szabályozás gondot okozott. A dơntéshozók végül arra a megoldásra jutottak, hogy egyszeri eljárás keretében az önkormányzatok is visszaigényelhetik az ÁFA-t.

A bürokratikus és hosszadalmas dơntéshozatal mellett a PHARE-források felhasználását megnehezíti a pályáztatás költségessége is. A pályázni készülö önkormányzatok egy része számára elrettentő erővel bír az a rendelkezés, hogy a pályázati díj az igényelt összeg fél százaléka, amelyet, mint ez hamar kiderült, vesztes pályázatok esetén nem fizettek vissza a pályázóknak. A csődhelyzetben lévő vagy csődközeli önkormányzatok számára így értelemszerüen nem nyílt meg ez a lehetőség. 


\section{A regionális területfejlesztési intézményrendszer müködésének első tapasztalatai}

A területfejlesztésröl és területrendezésröl szóló 1996. évi törvény 1999-es módosítása írta elö elöször kötelező érvénnyel a regionális fejlesztési tanácsok létrehozását, és szabta meg, hogy a létrejövő hét magyarországi régió területe és megyei összetétele a már korábban létrehozott tervezési-statisztikai régióknak feleljen meg. Az újonnan létrehozott, az EU-forrásokért pályázó, azok felhasználását koordináló, a pályázati kírásokért és a pályáztatás menedzseléséért felelős regionális tanácsok (RFT) két kivétellel még nem tekintenek vissza olyan hosszú múltra, hogy tevékenységüket elemezni, eredményeiket, müködési körülményeiket ismertetni lehessen. A magyarországi regionális szerveződésre mostanáig leginkább a régiók összetétele feletti vita nyomta rá a bélyegét (Kovács 1999). A másik vitatott pont a régiók székhelye volt. Egyes megyék önálló régióvá szerveződési igénye komoly indulatokat váltott ki, csakúgy, mint a megyehatár szentségét kétségbe vonó régiószervezödési javaslatok.

Témánk szempontjából annak a kêt régiónak (Dél-Alföld, Dél-Dunántúl) a tapasztalatai érdemelnek említést, amelyek kísérleti régióként már korábban érdemi munkalehetöséghez jutottak - azon túlmenöen, hogy jogilag megalakultak, müködni is kezdtek -, hiszen az 1996-os kísérleti PHARE-program keretében 4-4 millió eurós fejlesztési forráshoz jutottak. ${ }^{13}$

Az 1996-os PHARE országprogramban regionális fejlesztésre szánt 8 millió eurós keret pályázati feltétele volt, hogy legyen múködő regionális fejlesztési tanács, illetve müködjön annak munkaszervezete is, amely a pályázatok menedzseléséért, lebonyolításáért felelös. Ennek a feltételnek a fenti két régió tett eleget. A pályázati feltételeket 1998 nyarán hirdették ki. Az RFT-k októberre már feldolgozták, és el is bírálták a beérkezett pályázatokat. A nyertesek kihirdetése után kezdődött meg az elöbbi fejezetben ismertetett hosszadalmas döntési procedúra. A brüsszeli PHAREbizottság egy évvel (!) később, 1999 nyarára hagyta jóvá azokat a szerződésmintákat, amelyek alapján a tenderpályáztatást megkezdhették. Ezzel párhuzamosan (1999 nyarára) a budapesti PHARE-delegáció jóváhagyása is megszületett az RFT-k által támogatandónak ítélt pályázatokról. Az elvi jóváhagyás ellenére a PHAREdelegáció számos, nem pusztán formai módositást kért. Az alatt az egy év alatt, amíg a döntés az elvi jóváhagyásról megszületett, megváltozott az eredeti koncepció. Az eredeti ,irányvonal” szerint a regionális kohézió erösítése jegyében több pályázó összefogásával készült, közösen beadott pályázatok számíthattak támogatásra. Az elvi jóváhagyás során kiderült, hogy a pályázatoknak csak egy kedvezményezettje lehet, igy a pályázatokat szét kellett választani, az együttmúködésbe, közös pályázásba épp csak belekóstoló pályázóknak immár „egyénire fogalmazva” kellett a pályázatukat módosítva beadniuk. A korábbi kiírás szerint profitorientált szervezetek is beadhattak pályázatot. 1999 nyarára ezt a PHARE visszavonta, így a nyerteseknek megadott határidőn belül át kellett alakulniuk kht.-vá, vagy belépni egy kht. szervezetébe. 
Bár a kis összegü (az RFT-k hatáskörébe tartozó) tenderpályázatok meghirdetése, elbírálása már megkezdödhetett, a PHARE által is elfogadott kifizetési szabványbizonylat csak 2000 januárjában érkezett meg az RFT-irodákba. Ez alatt a másfél év alatt a magyarországi központi alapokból rendelkezésre bocsátott keretek határideje lejárt, a pályázóknak saját erővel kellett kiváltaniuk ezeket az összegeket. A 2000. évi költségvetési keretből elkülönitettek ugyan bizonyos összegeket erre a célra, ám, valószínüleg a hosszadalmas huzavona következtében a PHARE 97-es programra az idei elkülönített keret csak a fele a 2000-re ígért összegnek.

A vidék- és idegenforgalom-fejlesztésre, a KKV-k versenyképességének erősitésére, regionális marketingre és a regionális kohézió erősítésére számos kreatív, a megyék közötti együttműködést, integrált megközelítést tükrözö pályázat érkezett be. Az RFT-irodák bizakodóak: 2000-ben talán már sor kerülhet az 1996-os PHARE-alapokból történő első kifizetésekre. Az eddig csak a saját forrásaikat felhasználó, a pozitív döntést követöen már másfél éve várakozó pályázók így megkezdhetik a magyar költségvetésben elkülönített keretek felhasználását is.

Az 1997-es PHARE-program keretében megítélt regionális fejlesztési keretek tekintetében már nem ilyen ,jó" a helyzet. Regionális szinten mind a pályázók, mind az RFT-irodák (Dél-Dunántúli és Észak Alföldi Régió) rengeteg munkát és időt fektettek a pályáztatásba, pályázat-írásba, esetenként a saját erő felhasználása is megkezdődött a pozitiv döntések kihirdetését követően, ám mivel a magyar félnek (FVM PHARE Iroda és az RFT Ügynöksége), illetve a PHARE képviselöinek (helyi delegáció, PHARE brüsszeli iroda) a megadott legvégső határidőre (1999 végére) sem sikerült megállapodniuk a pályáztatás (közbeszerzés) lebonyolításának szabályozásában, jelenleg nem tudni, mi lesz a PHARE 1997-es országalapjából a regionális fejlesztésre fordítható keret sorsa.

A PHARE-pályázatok nehézkessége abból ered, hogy a PHARE brüsszeli szervezete és a magyar régiók közötti intézménylánc a jelenlegi formájában nem alkalmas a decentralizált finanszírozású területfejlesztés müködtetésére. A régiók nem tarthatnak közvetlen kapcsolatot a pályázati csomagok véleményezését és elbírálását végző helyi PHARE-delegációval, kizárólag az FVM PHARE-irodájának közvetítésével szerezhetnek információt a koncepcióról, annak módosulásáról, a bürokratikus folyamat pillanatnyi állásáról. A decentralizációból következỏen ugrásszerúen nött a pályázati projektek száma. A PHARE-delegáció hatalmas időkiesést eredményező szük keresztmetszetet képez a pályáztatási folyamatban, mivel nem megfelelő számú munkatárs foglalkozik a változó szakmai tartalmú (mind-mind önálló szakterületet képezó) pályázatok tömegének véleményezésével. A decentralizált területfejlesztés EU-hoz kapcsolódó finanszírozása nincs intézményszerüen kialakítva.

A több éves bürokratikus huzavona miatt azonban, egyrészt a magyar intézmények (az RFT-k, az amúgy remek pályázatokat beadó kamarák stb.) válnak hiteltelenné, másrészt visszájára fordul magának a PHARE pályázati rendszernek a megítélése: olyan programmal érdemes ma PHARE-pályázaton indulni, amelynek a megvalósulása nem létkérdés (!), vagy amire egyébként is van elegendő hazai forrás. 
A területfejlesztésröl és területrendezésröl szóló törvény 1999-es módosítása értelmében, már mind a hét régió fejlesztési tanácsa megalakult. Többségük a regionális fejlesztési stratégia kidolgozását kezdte csak meg. Az említett két kísérleti régióban már a stratégiáknak konkrét tartalmat adó programot is kidolgozták, amelyet az RFT-k igen hosszú viták, egyeztetések és módosítások után el is fogadtak. A tárcák (FVM, GM) ettől függetlenül, nem sokkal az elfogadó határozatot követően, ezeknek a régióknak is megküldték a stratégiai program készítésére vonatkozó felhívásukat, és részletes irányelveket adtak meg arra vonatkozólag, hogy miként épüljön fel a program. Mivel a két tárca programkészítésre vonatkozó elöírásai meglehetősen különbözőek, a programjaikat már elkészitett, egyeztetett, megvitatott és elfogadott régiók, két párhuzamos, az egyes tárcák különbözö elvárásainak megfelelő program készítését kezdték el ismét.

A megyei szintủ stratégiai koncepciók és programok kidolgozásához képest, amelyek esetében semmiféle központi irányelv nem próbálta megbéklyózni, mederbe terelni a helyi szakemberek szárnyaló fantáziáját, a tárcairányelvek jelenlegi rendszere egyértelmủ visszalépést jelent a „tervlebontás” mechanizmusát idézve fel. Mindez már csak azért is érthetetlen, mert a régiószintủ stratégiai tervek és programok a nemzeti fejlesztési programmal párhuzamosan készülnek, vagyis se azt nem állíthatjuk, hogy a nemzeti fejlesztési program a régió-programokra épülne, sem azt, hogy a régiószintủ programok készitőinek alkalmuk lenne a nemzeti fejlesztési program irányelveit figyelembe venni. Az egymásra épülés hiányában a régiószintủ programok a megyei programokhoz hasonlóan még sokáig csak kívánságlistának minősülnek. Funkciójuk ebben a megközelítésben az, hogy a régiószintü problémákat és fejlesztési terveket, prioritásokat dokumentálják. Így még inkább érthetetlen, miért tekintik az egyes tárcák létkérdésnek, hogy a programok az ő irányelveiknek megfelelően épüljenek fel - annál is inkább, mert a decentralizáció mértékét és múködési mechanizmusát vizsgáló nyugati szakértök egyik legelsö, sokatmondó következtetésekre alkalmat adó kérdése az, hogy milyen szinten alakul ki a decentralizált programozási rendszerben a programok tartalma, léteznek-e központi irányelvek? (Smoke 1999) Megjegyzendő, a nyugati szakértők kevésbé kárhoztatják a hatékony tervlebontásra épülő, és ilyen módon eredményes regionális modernizációt megvalósító rendszereket, mint a fent leírt, párhuzamosan alakuló, de egymással köszönő viszonyban sem lévő programozási mechanizmusok rendszerét.

Végül, egyetlen megjegyzés az intézményrendszer kiépülésének furcsaságairól. Az RFT-k és az MTT-k együttmüködése több helyen úgy valósult meg, hogy az RFT-k a régióba tartozó minden egyes megyében létrehoztak egy-egy helyi szervezetet. Ezáltal párhuzamos intézményrendszer jött létre, amely óhatatlan hatásköri villongásokhoz vezet.

A területfejlesztéssel foglalkozó tanulmányok nem megkerülhető része az állásfoglalás a „Megye vagy régió?" leegyszerủsített kérdésében. A kérdést úgy is feltehetjük, hogy az EU-konform intézménystruktúra meghonosítása és hatékony müködtetése érdekében megszüntetve, leépítve, átalakítva kell-e meghaladni a szerves 
fejlődéssel létrejött, de az EU-konformitás próbáját ki nem álló megyei intézményrendszert? A másik lehetőség az lenne, hogy az eddigi keretek között felhalmozott tudást és tapasztalatokat megőrizve a megyei intézményrendszert a kialakítandó EU-konform területfejlesztési struktúra egyik meghatározó paraméterének tekintjük. A szerző ez utóbbi változatra szavaz. Nem kérdés, hogy a régió szintjét fejleszteni, erősíteni kell, de nem úgy, hogy a megyei, tehát az alsóbb szinttől vesszük el a hatáskör egy részét és adjuk át a régióknak, hanem felülröl, kormányzati (tárca) szintről delegálunk hatás- és feladatkört regionális szintre.

\section{Az EU-konform területfejlesztés megvalósításának hiányosságai}

Az EU-konform területfejlesztési programkészítés egyik alapszabálya, hogy komplex regionális fejlesztési programok készüljenek. Komplex programcsomagnak nevezzük valamilyen területi rendezőelv szerint összesített, egymással összefüggő projektek összességét. A komplex területfejlesztési programok a gazdaságés infrastruktúra-fejlesztés mellett olyan projekteket tartalmaznak, amelyek a fenti két alapcélhoz, a fenti két célra benyújtott projekt-pályázatokhoz kapcsolódnak, megvalósításukat elösegítik.

A programok ilyen építőeleme a különböző projektekkel összefüggő humán erőforrás-fejlesztés: a befektetés-ösztönzési projektekhez a potenciális vállalkozók képzése kapcsolódik, a turizmus fejlesztéséhez a nyelvi képzés stb. A komplex programok épitőelemei a térségi integrációt, regionális kohéziót szolgáló programok. Ide tartozik a regionális identitás kialakítása, a régió kapacitásainak, lehetőségeinek megjelenítése a potenciális befektetök felé. Ez utóbbi két programelem kapcsolódik a befektetés-ösztönzés, gazdaságfejlesztés céljához is, csakúgy, mint az adott régióban több pályázó együttmüködését tükröző, közösen benyújtott pályázatok támogatása.

Komplex csomag megvalósulása esetén az egyes projektek közötti szinergiahatásnak köszönhetöen a régió egészének fejlödése nagyobb léptékü lesz, mint a támogatott részterületek fejlődésének ,összege".

Ami a konkrét megyei tapasztalatokat illeti, a komplexitás elve csupán a feladatkijelölö (az MTT-k kifejezésével: ,a kívánságlistát tartalmazó”) stratégiai koncepciókban érvényesül, a pályázatkiírások szintjén már nem. Nem is lehet másképp, hiszen a komplexitás elve átfogó szemléletet, megtervezettséget, hosszabb távú (nem éves szintü) tervezést feltételezne.

A teruletfejlesztési programok egyes, komplexitást biztosító elemeivel kapcsolatos tapasztalatok meglehetős szóródást mutatnak, a teljes csalódottságtól az alapvetöen pozitiv megítélésig.

Ami a humán eröforrások fejlesztését illeti, nem csupán a végcél, a piaci igényeknek megfelelö képzettség területén vannak jelentős elmaradások, hanem a területfejlesztés képzést támogató eszközrendszerében is. Az elmaradottságuk okán kiemelt megyék tapasztalatai alapján (vagyis azokban a megyékben, ahol nem csupán a stratégia kialakítására került eddig sor, hanem már a programok megvalósulásáról is vannak 
tapasztalatok) a képzés kimaradt a felzárkóztatási, szerkezet-átalakítási programokból. A humán eröforrások fejlesztéséhez ugyanis nem kapcsolódott központi pénzalap, sőt a decentralizált kereteket sem lehetett erre a célra igénybe venni, ezekből nem lehetett képzést közvetlenül támogatni. Bár a humán eröforrások fejlesztése minden megye stratégiai koncepciójának kiemelt részét képezi, ez a terület valószínüleg a közeljövöben sem kerül a decentralizált keretekkel támogatható prioritások közé, hiszen minisztériumi központi alap továbbra sincs hozzárendelve, és a PHARE 2000 támogatás prioritásai között sem szerepel. A humán erőforrások fejlesztése, mint területfejlesztési programelem, eddig kizárólag a két kísérleti régió forrásokhoz még mindig meg nem juttatott, de már elfogadott programjaiban szerepelt.

A regionális kohéziót szolgáló több, azonos régióbeli, de különböző megyékhez tartozó pályázó együttmüködését előmozdító pályázatok ezzel szemben sikeresek voltak. Mivel a pályázati kiírás egyértelmüvé tette, hogy együttmüködést tükröző, közösen beadott pályázatoknak van esélye a támogatás elnyerésére, rendkívül kreatív ötletek születtek; az addig szeparáltan múködö intézmények felvették egymással a kapcsolatot, közös pályázatokat nyújtottak be, és sokan el is nyerték a támogatást.

Az EU-konformitás másik alapelve a szubszidiaritás. Az elv az autonóm intézmények természetes munkamegosztását és kooperációját mondja ki. Ennek alapján minden feladatot azon a lehetö legalacsonyabb kormányzati szinten kell elvégezni, ahol arra a legtöbb információ áll rendelkezésre. Ezen az elven alapul az alulról felfelé építkezö területfejlesztési stratégia: a helyi szereplök - helyi önkormányzatok, kistérségi önkormányzati területfejlesztési társulások - együttmúködnek a megyei területfejlesztési tanácsokkal, közremúködnek a megyei stratégia összeállításában. Ez utóbbiak a regionális területfejlesztési tanácsokon belül jutnak el közös álláspontra, és a regionális tanácsok fejlesztési koncepciói kerülnek a központi kormányzat elé. Ebből áll össze, ezekre épít a nemzeti fejlesztési stratégia. A gyakorlatban felmerült a „tyúk vagy a tojás" probléma, hiszen elvben, a megfelelö szürökön átjutva, valóban a helyi elképzeléseknek kell testet ölteniük az országos területfejlesztési koncepcióban, de gyakorlatban az óhajok (a jövőkép) felvázolásán túlmenően nehéz úgy konkrét fejlesztési programokat kidolgozni, hogy a megyék nincsenek tisztában a középtávon rendelkezésükre álló forrásokkal, az országos koncepcióban a megyét érintő fejlesztési prioritásokkal. A nemzeti fejlesztési program most készül, és a megyék egy része meg van győződve arról, hogy az országos program és a helyi elképzelések nem lesznek köszönö viszonyban.

Egy másik, az értékelések (pl. EU-országjelentés) szerint már megvalósult elv a decentralizáció szükségessége. Bár létezik decentralizációt tükrözö intézményrendszer, a kormány centralizációs törekvései lépten-nyomon éreztetik hatásukat. Az MTT-k a sajtóból értesültek arról, hogy Magyarország milyen konkrét programokkal kívánja kitölteni az EU előcsatlakozási ISPA alapjából számára rendelkezésre álló keretet. ${ }^{14} \mathrm{~A}$ pályázatok tartalmát a megyékkel nem egyeztették.

Korábban volt arra precedens, hogy egy MTT elnöke meghívta a megyébe a központi pénzalapok képviselőit, és megpróbált valamilyen együttmüködést létrehozni 
a pályáztatás területén. Közös pályázati kiírásokat kezdeményezett, közös bírálati szempontok kialakítását szorgalmazta. Javasolta, hogy a felek rendszeresen konzultáljanak egymással arról, hogy mely alapokból, milyen típusú pályázatokat támogatnak. Ilyen módon össze lehetne hangolni a területi fejlesztési célokat a tárcacélokkal. A kezdeményezésböl nem lett semmi, a tárcák, a központi alapok képviselői nem tartották, nem tartják szükségesnek az egyeztetést.

A kormány centralizációs törekvései erőteljesen befolyásolják a multik és a helyi; illetve megyei önkormányzatok kapcsolatát. Fejlesztési terveikröl, igényeikről a multik nem az MTT-kkel tárgyalnak, hiszen azok eszköztelensége, minimális mozgástere számukra jól ismert. Tárgyalást így általában a szakminisztériumokkal, a Miniszterelnöki Hivatallal, illetve legújabban leginkább magával a miniszterelnökkel kezdeményeznek. A megyei érdekeket képviselő, a megyei szük keresztmetszetekkel és lehetőségekkel leginkább tisztában lévő intézmények képviselöinek így nem nyílik lehetősége arra, hogy a térségükben tevékenykedő multik kezdeményezéseit a megye szempontjából kedvezö mederbe tereljék, rámutassanak arra, hogy mely területeken volna szükség a multik együttmüködésére, a helyi fejlesztési tervekhez való hozzájárulására. Természetesen szó sincs arról, hogy az MTT-k képviselöi komoly anyagi ráfordítással járó infrastrukturális és egyéb fejlesztéseket próbálnának kicsikarni a multiktól (annak ellenére, hogy egyes terveik megvalósítása érdekében a cégek nem csekély áldozatra hajlandók, melynek hozadéka így nem megyei szinten és nem fejlesztési hozzájárulások formájában jelenik meg). Az interjúk tanúsága szerint olyan országos és regionális szinten egyaránt létkérdésnek tartott programok, mint a $\mathrm{K}+\mathrm{F}$-fejlesztés, vagy a beszállítói hálózat sürítése, a multik integrálása a hazai gazdaság vérkeringésébe nagy lökést kaphatna a multinacionális vállalatok és az MTT-k képviselói közötti tárgyalások során. Ilyen alkalmakat fel lehetne használni arra, hogy a cégek képviselöit megismertessék a helyi kutatási kapacitással, és rámutassanak arra, hogy kölcsönös elönyökkel járna, ha a helyi kutató intézetek megrendeléseket kapnának a multiktól. Hasonlóképpen, ezeken a tárgyalásokon lehetne a lokális viszonyokat nem kellőképpen ismerő betelepült cégek képviselöit megismertetni a beszállitásra alkalmas helyi KKV-kal, és rávenni őket arra, hogy növeljék termelésük helyi részarányát. Ha azonban ezek a tárgyalások kizárólag kormányzati, miniszterelnöki szinten folytatódnak, esély sincs arra, hogy a multik regionális kötödése erösödjön.

\section{A regionális politika döntéshozói számára megfogalmazott javaslatok}

Helyi fejlesztési programok helyett központi célok megvalósítása, választott testületek helyett többségében politikai delegáltakból álló döntéshozatal; kis túlzással azt állithatjuk, hogy a „decentralizált” területfejlesztési intézményrendszer konkrét mủködésére lassanként illik majd Beér Jánosnak az ötvenes évek elején keletkezett szemléletes megállapítása: „A helyi tanácsok nem a helyi hatalom szervei, hanem a hatalom helyi szervei" (Pálné Kovács 1997, 51). 
A területfejlesztési politika hatékonyságának javulása szempontjából létkérdés, hogy a helyi sajátosságokat jól ismerő MTT-k mozgástere, döntési szabadsága növekedjen, hogy jogosítványaik a feladataik mértékéhez igazodjanak, hogy maguk határozzák meg a helyi fejlesztési prioritásokat, hogy valóban gazdálkodjanak is a területfejlesztés címén ,általuk" szétosztható összegekkel.

A döntési jogosultság és a fejlesztési keretösszegekkel való gazdálkodás valódi decentralizációja már csak azért is könnyen megvalósítható, mert a helyi területfejlesztési stratégiák eredményei mérhetőek, az MTT-k ellenörzése megoldható, mutatószámokkal nyomon követhetö, hogy meghatározott időszak alatt mit sikerült a fejlesztési stratégiából megvalósítani.

Az MTT-k által pályáztatható decentralizált pénzeszközök a nem kiemelt megyék esetében rendkívül szükösek. A költségvetésbe foglalt, területfejlesztésre fordítható összeg összértékénél a decentralizált pályázati rendszerben szétosztható összegek összértéke jóval kevesebb. ${ }^{15}$ A fennmaradó összeg az egyes tárcák között oszlik meg. Amennyiben a tárcák hozzájárulnának ahhoz, hogy a területfejlesztésre fordítható tárcakeretek egy részét szintén decentralizáltan osszák el, nagyobb lenne az esélye annak, hogy megyei szinten átfogó területfejlesztési programokat valósítsanak meg.

Az átfogó, hosszabb távú tervezést az is akadályozza, hogy a támogatási rendszerben elkülönül a területi és az ágazati elv. A központi alapokból területfejlesztésre fordított összegek célszerübb, megtervezettebb felhasználását elösegítené, ha az egyes tárcáknál készített stratégiák nem kizárólag ágazati, hanem regionális szemléletet is tükröznének.

Problémát jelent, hogy a jelen pályázati rendszerben a gazdaságfejlesztés a rendelkezések értelmében túl szoros kapcsolatban áll a munkahelyteremtéssel. A pályázati rendszerbe külön kategóriát kellene beiktatni, amely technológiai korszerüsítést is lehetövé tenne. Így az a pályázó sem zárná ki magát automatikusan a támogatási feltételek közül, aki technológiai korszerüsitést hajtana végre, ezzel a hatékonyságát és versenyképességét javítaná, ám ennek következtében leépítené foglalkoztatottjainak egy részét.

Létkérdés, hogy Magyarország, a magyar régiók az eddigieknél hatékonyabban, sikeresebben férjenek hozzá az EU területfejlesztési forrásaihoz. Ehhez arra van szükség, hogy a magyar források felhasználási technika tekintetében össze legyenek hangolva az EU-források felhasználási szabályaival. A magyar területfejlesztési forrásokat nem lenne szabad a magyar költségvetés éves mozgásához kötni. Bármennyire is sérti a tárcaérdekeket, a PHARE-ra vonatkozó magyar kötelezettségeket egy költségvetési sorban kellene feltüntetni annak érdekében, hogy magyar és Európai Uniós forrásokat kombinálva, integrált területfejlesztési programokat finanszírozhassanak, valósíthassanak meg.

Összefoglalva, az interjúk tapasztalatai választ adtak a tanulmány elején feltett kérdésekre, jelesül, hogy képesek-e a döntéshozók regionális politikai eszközökkel iparfejlesztési célokat és a gazdaság szerkezetének modernizációját megvalósítani, 
a gazdasági tevékenységet élénkíteni? Kiderült, hogy a gazdaságpolitika egyes funkcionális céljainak megvalósítása akkor lehet igazán eredményes, ha az átfogó tárcastratégiák az adott ágazat, szakterület regionális adottságaiból kiinduló stratégiákra épülnek, illetve, ha a stratégiai programok megvalósítása, a központi programokon túlmenően valóban decentralizált módon történik. A kérdésekre adott válasz: elvileg igen. A regionális politika jelenlegi felemás tapasztalatai és mérsékelt eredményei pusztán azt tükrözik, hogy a fenti elveknek ma még nem sok közük van a valósághoz.

\section{Összefoglaló}

\section{Miként változott a magyarországi regionális politika az 1996-os területfejlesztési törvény nyomán?}

A területfejlesztési intézményrendszer müködésének gyermekbetegségei, a decentralizációs folyamat vontatott elörehaladása, a decentralizált keretek szükössége ellenére, valamint annak ellenére, hogy az alapinfrastruktúra fejlesztése továbbra is domináns szerepet játszik a területfejlesztésben, megállapíthatjuk, hogy az utóbbi három évben látványosan fejlödtek a területfejlesztés alanyainak és alakítóinak eszközei, lehetőségei, képességei. Kialakult a területi szemlélet, megszủnt a gazdaság kizárólagos ágazati elven való szervezỏdése, irányítása, fejlesztése.

A területfejlesztés célrendszerében az eddigi szociálpolitikai és infrastrukturális megközelítés mellett megjelent és egyre nagyobb teret hódít a gazdaságfejlesztési, befektetés-ösztönzési célrendszer. Az EU-programokhoz hasonlóan, igaz, egyelöre csak a stratégiai koncepciók és kevésbé a konkrét, támogatást nyert pályázatok szintjén, de már megjelentek a komplexitást biztosító programelemek: a humán erőforrások fejlesztésének igénye, a tercierizálódás ösztönzése, a regionális kohézió erösítése, a környezetvédelem.

Egy, a kilencvenes évek elején keletkezett tanulmányában Ágh Attila azt vizsgálta, hogy a nemzetközi közösség nyomására demokratizált országokban (az ún. homlokzatdemokráciákban, mint pl. Németország, Ausztria, Olaszország és Japán a második világháború után) mekkora az esélye a külső kényszer hatására létrehozott demokratikus intézményrendszer szervesülésének (Ágh 1992). A területfejlesztés magyarországi intézményrendszerének meghonosítása sok hasonlóságot mutat a tanulmányban elemzett esetekkel. A magyarországi közegben rendszeridegen, kész formaként meghonosítandó intézményrendszer létrehozását ,elöíró” külső kényszer ugyan finomabb, mint a háborús kapitulációt követően demokratizált országokban, hiszen Magyarország esetében a nemzeti törvényhozás önként vállalt EUharmonizációjáról van szó. Az alaphelyzet és az ebből fakadó problémák ugyanakkor nagy hasonlóságot mutatnak: a ,sztenderdizált hardvert” átvevő országban meg kell birkózni az intézményrendszer rendszeridegenségéből fakadó alacsony legitimációval, mủködésének diszfunkcióival; el kell érni, hogy az intézményrendszer szervesüljön. 
A „kifinomult külső kényszer” ékes példája a regionális fejlesztést támogató PHARE-keretek felhasználásának lehetősége. Borsod-Abaúj-Zemplén megye példája sokat elárul: az 1995-98-as integrált szerkezet-átalakítási program megvalósítása során a PHARE először is „kikényszerítette” a források, a tárcakeretek eurokonform integrálását. (Más kérdés, hogy a korábbi tárcaegyezkedések a megye és külön-külön minden egyes tárca között még akkor sem maradtak el, amikor a tárcakereteket már valóban egyetlen költségvetési sorba integrálták.)

Az integrált szerkezet-átalakítási program hatalmas szellemi és anyagi potenciált mozgósított, sokezer oldal szakértói anyag készült, esély nyílt arra, hogy kívánságlistán túlmenő, középtávú víziót alkossanak és valósítsanak meg. A PHAREalapokból, a magyar tárcakeretekböl és az elkülönített állami alapokból erre a célra mozgósított összegek a decentralizált keretekkel együtt sokszorosan (esetenként 8 10-szeresen) meghaladták a más megyék számára területfejlesztési célokra szánható összegeket. Ugyanakkor, ha belepillantunk a részletes kimutatásokba, kiderül, hogy az 1995-98-as időszakban Borsod-Abaúj-Zemplén megyében az integrált szerkezetátalakítási program keretében rendelkezésre álló 15,273 milliárd forintból, PHARE-forrás összesen 451 millió $\mathrm{Ft}$ (!) volt. ${ }^{16}$

A nemcsak a várakozásokhoz, de az ígéretekhez képest is megdöbbentően csekély PHARE-szerepvállalás mindazonáltal jó hatást gyakorolt az intézményrendszer szervesüléséért felelös szereplőkre: mind kormányzati, mind regionális szinten, mind a helyi pályázók szintjén sikerrel mozgósította őket. Hozzájárult a területfejlesztési intézményrendszer korszerüsödéséhez, új intézmények megjelenéséhez, eurokonform módszerek átvételéhez és nem utolsó sorban ahhoz, hogy magyar gazdaságpolitikai döntéshozók, költségvetési forrásokra alapozva, a rendszerváltást követö gazdaságtörténetben páratlan módon egy-egy költségvetési évnél hosszabb távú stratégiai tervezést kezdeményezzenek - mindezt anélkül, hogy az Európai Unió adófizetöi erre a célra jelentősebb összeget áldoztak volna.

Bár a kilencvenes évek második felében a régiószintü fejlesztés intézményrendszerének beindítása hasonló körülmények között, hasonlóan nem egyértelmü PHARE-szerepvállalással kezdődött meg, úgy tünik, „segítségükkel” elértük, hogy a „homlokzat” már eurokonform. A tapasztalatok pozitívak: az átvett hardver lassan, de kezd „szoftverrel telítődni”, beágyazódni az intézményrendszer korábban létrehozott elemei közé, át is alakítva azt.

$\mathrm{Az}$ intézményrendszer létrehozását követően kialakult a területfejlesztés módszertana is: a megyei területfejlesztési tanácsok és a kísérleti régiók képviselöi számos olyan képzési programon vettek részt, tanulmányúton jártak, ahol a külföldi (EU) példákat, módszereket tanulmányozhatták, információhoz, dokumentumokhoz juthattak. A Megyei Területfejlesztési Tanácsoknál, illetve a fejlesztési tanácsadással foglalkozó cégekben (amelyek tagjai sokszor volt MTT-alkalmazottakból kerülnek ki) olyan tudásmennyiség van felhalmozódóban, amely elvileg megkönnyíti az EU elócsatlakozási alapjaiból finanszírozott, területfejlesztési programjaiba való bekapcsolódást, de legalábbis nem a magyarországi stratégia-, program- és pályázat- 
alkotási képességek hiányára lesz majd visszavezethetö, ha az EU elvileg rendelkezésre álló kereteiből Magyarország viszonylag keveset lesz képes felhasználni.

\section{Jegyzetek}

'A ,regionális" kifejezés nem a ,tervezési-statisztikai régió"-ra utal ebben a tanulmányban. A szónak az angol ,regional" kifejezésnek megfeleb̉en területi jelentése van, elvileg mindenfajta területi egységet jelöl (körzet, kistérség, térség, megye, tervezési-statisztikai régió stb.), jelen tanulmányban pedig leggyakrabban megyei szintre, esetenként a régió szintjére utal.

${ }^{2}$ Területfejlesztési célok megvalósítására háromféle decentralizált pályázati ebirányzat létezik. Az első a területfejlesztés kedvezményezett térségeiben igénybe vehetó területi kiegyenlítési keret. Erre kizárólag önkormányzatok pályázhatnak, és a megítélt összegeket többnyire infrastrukturális fejlesztésre fordítják. A második az egyéb (nem infrastrukturális) célokra is fordítható, területfejlesztési céleb́irányzat. Ezt a gazdaságfejlesztésre is fordítható decentralizált keretet 1998-ig területfejlesztési, 1999ben vidékfejlesztési célelöirányzatnak hívták. 2000-ben az elöcsatlakozási alapok szerkezetének pontosabb megismerésével ismét a régi elnevezést használják. Az FVM-n belül külön vidékfejlesztési és területfejlesztési fỏosztály alakult, ami elörevetíti, hogy a vidékfejlesztés valószinüleg új pályázati előirányzatként különül majd el a területfejlesztésôl. A harmadik elóirányzat-típus a céljellegü decentralizált támogatási keret. Ez a keret az önkormányzatok felhalmozási kiadásaihoz járul hozzá, illetve a megítélt keretösszeg 20\%-át az önkormányzatok kötelesek a Vis Maior Alapba fektetni.

${ }^{3}$ A bekezdésben szereplö 59,3\% nem azt jelenti, hogy a decentralizált területfejlesztési keretek 40,7\% át fordították 1997-ben infrastrukturális fejlesztésekre. Ez az arány pusztán a területfejlesztési célebirányzatra vonatkozik. Infrastrukturális fejlesztésekre fordították ezenkívủl a terủleti kiegyenlítést szolgálo fejlesztési támogatásokat, továbbá a céljellegü decentralizált tảmogatások egy részét is.

${ }^{4}$ Az Antall-kormány koncentrált államigazgatás (vármegyék, f́ispánok) kialakítását célzó, tradicionális szemléletet tükrözö tervei és az SZDSZ legteljesebb települési autonómiát garantálni, a megyei szintet „kiiktatni" kívánó törekvése közötti rossz politikai kompromisszumot részletezi Ágh (1999). Pálné Kovács Ilona (1999) a „terhes örökséget" abból a szempontból veszi nagyító alá, hogy az miként befolyásolja, tereli kényszerpályára ma a regionális politika reformtörekvéseit.

${ }^{5}$ A regionális szerveződést ez a törvény még csak lehetôségként tüntette fel, eszerint, a megyék, alulról jövő kezdeményezéssel regionális szervezeteket alapithattak. Mivel ilyen alulról jöő kezdeményezésre csak két régióban kerullt sor - a toobbi régióban a regionális hovatartozás és a régió székhelye feletti viták megakadályoztảk a szervezödés intézményesülését - az 1999. évi törvénymódosítás átvágta az elfajuló viták gordiuszi csomóját, és kötelezỏ jelleggel elöirta a regionális területfejlesztési tanácsok és munkaszervezeteik létrehozását, mégpedig a tervezési-statisztikai régióknak megfeleló beosztásban.

${ }^{6}$ A monitoring formai és tartalmi követelményei, egyáltalán maga a monitoring mind a mai napig nincs meghatározva. Az egyik meginterjúvolt szakért̋̉ szerint most készül az a kormányrendelet, amely definíciót ad, rögzíti a feladatokat, hatásköröket és a követelményeket.

'A nagyfokú „intézményi bizonytalanságra” tekintettel 2000 elején a PHARE felfüggesztette a PHARE 97-es program végrehajtását.

${ }^{8}$ A pályázó nem a megyei decentralizált keretböl, hanem a központilag kezelt Gazdaságfejlesztési Caelöirányzatból kért tảmogatást.

9 A helyszín Borsod-Abaúj-Zemplén megye, ahol a PHARE Kísérleti Fejlesztési Programja 1995-ben kezdödött.

${ }^{10}$ Rechnitzer (1998) tartalmi és tervezési, módszertani szempontból összehasonlítja a 19 megye területfejlesztési koncepcióját. A 223. lapon szereplő szemléletes összefoglaló táblázatból kiderül, hogy a 19 megyéből 12-ben a stratégiai koncepció még kívánságszinten sem határoz meg finanszírozási forráskat.

"1994-95-ben a terulletfejlesztési támogatásokat még elkülönített alapból, a Területfejlesztési Alapból folyósították. Mivel azonban a Területfejlesztési Alap forrásainak túlnyomó része költségvetési támogatásból, illetve privatizációs bevételekböl származott, az 1995. évi államháztartási reform keretében az Alap fejezeti elöirányzattá alakult át (Szaló 1999).

${ }^{12}$ Ez történt az 1997-es PHARE kísérleti régió programjában nyertes régiókkal (Dél-Dunántúli és ÉszakAlföldi Régiók).

${ }^{13}$ Pontosabban, a támogatási szerzodéseket már aláirták és valószínüleg a fejlesztési ügynökségek hamarosan hozzá is jutnak ezekhez az összegekhez. 
${ }^{14} \mathrm{Az}$ Instrument for Structural Policies Pre-Accession (ISPA) elöcsatlakozási alapból kömyezetvédelmi és infrastrukturális fejlesztésekre lehet támogatásért pályázni.

15 1998-ban 19,8 milliárd Ft, 1999-ben közel 22 milliárd Ft terulletfejlesztési támogatás felhasználásáról dönthettek a megyei területfejlesztési tanácsok, ami a területfejlesztésre szánt összes, költségvetésben szereplö keret összértékének kb. 5\%-át jelenti. (Szaló 1999; Gyarmathy 1998). Ez az arány természetesen erösen vitatott, hiszen - mivel minden funkcionális programnak van területi vonzata is - kérdés, hogy mit tekintünk „terulletfejlesztésre szánt” összegnek.

${ }^{16}$ A programban eredetileg 23 millió ECU felhasználásáról döntött a PHARE. Ebből az összegböl végül 5 millió ECU-t folyósítottak, melyböl 2 millió ECU-t (451 millió Ft) használtak fel magának az integrált szerkezet-átalakítási programnak a keretében.

\section{Irodalom}

Ágh A. (1992) A kényszerdemokrácia paradoxonjai. - Társadalmi Szemle. 12. 3-14. o.

Ágh A. (1999) Önkormányzatiság a magyar demokratizálásban: Helyi önkormányzatok és alkalmazkodás az EU-hoz. - Politikatudományi Szemle. 2. 65-94. o.

Dancs L. (1999) A területfejlesztési tanácsoké a jövö? - Comitatus. 10. 49-51. o.

Gyarmathy M. (1998) A területfejlesztésröl és a területrendezésröl szóló 1996. évi XXI. Törvény végrehajtásának tapasztalatai Borsod-Abaúj-Zemplén megyében. - Magyar Közigazgatás. 11. 684-688. o.

Hajdú Z. (1999) A régió tértörténeti problematikája Magyarországon, - Info-Társadalom-Tudomány. 44. 21-29. o.

Horváth Gy. (1998a) Európai regionális politika. Budapest-Pécs, Dialóg-Campus Kiadó.

Horváth Gy. (1998b) Regional and Cohesion Policy in Hungary. Pécs, Centre for Regional Studies Hungary. Discussion Paper No. 23.

Horváth Gy. (1999) A régiók Európában. - Info-Társadalom-Tudomány. 44. 7-20. o.

Kiss J. (1998) Az ágazati gazdaságszerkezet szerepe a regionális differenciálódásban Magyarországon. Tér és Társadalom. 1-2. 138-162. o.

Kovács T. (1999) Polémia a magyarországi régiókról. - Területi Statisztika. Március. 107-1 16. o.

Pálné Kovács I. (1997) Lokális és regionális politika. - Politikatudományi Szemle. 2. 47-69. o.

Pálné Kovács I. (1999) Régiók az ezredfordulón? A terhes örökség és a jövő modernizációs kihivásai. Tér és Társadalom. 3. 59-77. o.

Pfeil E. (1999) Vázlat a területi tervezés és a kỏzigazgatás kapcsolatáról, avagy regionalizálás a területi tervezés szemszögéböl. - Tér és Társadalom. 3.79-99. o.

Rechnitzer J. (1998) Terïleti stratégiák. Budapest-Pécs, Dialóg Campus Kiadó.

Szaló P. (1999) A területfejlesztés intézményrendszerének kiépitése és jövőbeli feladatai. - Magyar Közigazgatás. 1-2. 8-17 o.

\section{REGIONAL INVESTMENT PROMOTION IN HUNGARY}

\section{ANDREA SZALAVETZ}

The paper is based on the results of field investigations carried out at various representatives of the decentralized institutions of regional development. It seeks to discover the real level of decentralization, the functioning and the limits of the newly created institutions, as well as the way, how EU-principles of programming and decentralization are put into practice.

The conclusions of the paper are the following:

1) The decentralization of regional development is still rather formal. 
2) Instead of strategic development, County Development Councils play a pure administrative role.

3) Regional development is almost as fragmented as the Hungarian settlement structure: although the elaborated county development programs are complex, including objectives like human resource development, regional cohesion, investment promotion etc. the concrete projects that are supported mostly target the internal infrastructure of individual settlements: i.e. settlement development, instead of regional development.

4) The centralization efforts of the government prevent locally operating multinationals from becoming more committed in their region's development.

5) Investment promotion is too strictly tied to job creation, which may bias against technological upgrading.

6) The bureaucratic decision-making of PHARE strip the credibility also from the Hungarian institutions. 